Supporting Information

\title{
AIE-Active Random Conjugated Copolymers Synthesized by ADMET Polymerization as a Fluorescent Probe Specific for Palladium Detection
}

Xiaoqing Liu, ${ }^{a, b}$ Taixin Chen, ${ }^{b}$ Feng Yu, ${ }^{b}$ Yuxuan Shang, ${ }^{b}$ Xue Meng, ${ }^{b}$ and Zhong-Ren Chen $*^{a, b}$

${ }^{a}$ Shenzhen Grubbs Institute, Southern University of Science and Technology, Shenzhen 518005, China

${ }^{b}$ Department of Chemistry, Southern University of Science and Technology, Shenzhen 518005, China

Table of Contents

1. Synthes is of monomers

2. Synthes is of polymers

3. Molecular we ights de termined by GPC in THF

4. Structural Characterization of DDB V-containing polymers

5. Integration analys is of ${ }^{1} \mathrm{H}$ NMR spectra to de termine $f_{\text {[TPE] }}$

6. The rmal measurements

7. Optical properties of ADMET monomers and hompolymers

8. Fluorescence life times of polymers

9. The limit of detection for $\mathbf{P d}^{2+}$

10. Modified Stern-Volmer tre atment of quenching data

11. Metal ions de tection

12. Comparison of the de tection for $\mathbf{P d}^{2+}$ by conjugated polymers

13. References

14. ${ }^{1} \mathrm{H}$ NMR and ${ }^{13} \mathrm{C}$ NMR spectra of compounds 


\section{Synthesis of monomers}

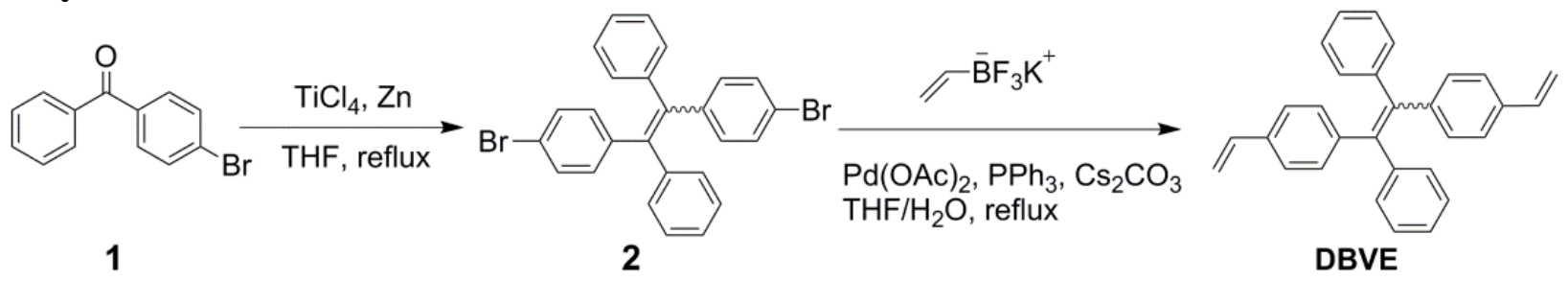

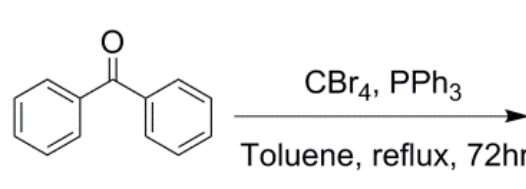

3<smiles>BrC(Br)=C(c1ccccc1)c1ccccc1</smiles>

4

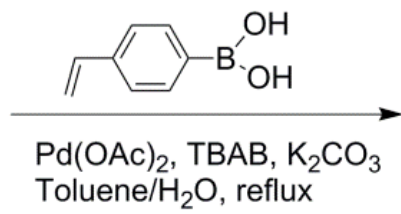

Toluene/ $\mathrm{H}_{2} \mathrm{O}$, reflux

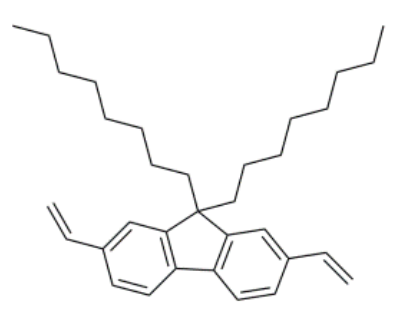

Flu

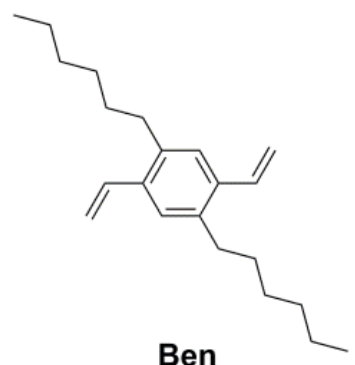<smiles>C=Cc1ccc(C(=C(c2ccccc2)c2ccccc2)c2ccccc2)cc1</smiles>

DDBV

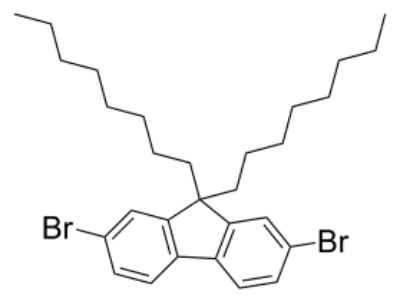

5

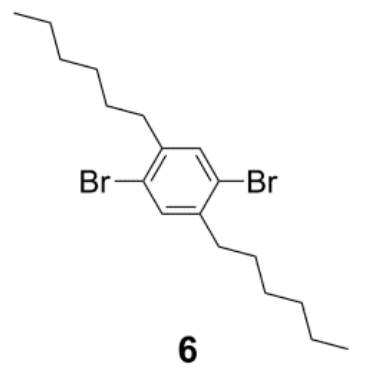

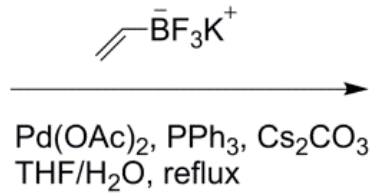

$\mathrm{THF} / \mathrm{H}_{2} \mathrm{O}$, reflux

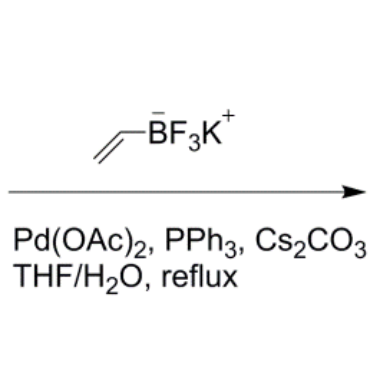

Scheme S1. Synthesis routes of ADMET monomers.

Synthesis of DBVE

\section{1,2-bis (4-bromophenyl)-1,2-diphe nyle the ne (2)}

Into a $250 \mathrm{~mL}$ two-necked round-bottom flask with a reflux condenser were placed 4-bromobenzophenone (1, $5.22 \mathrm{~g}, 20 \mathrm{mmol}$ ) and zinc powder (2.61 g, $40 \mathrm{mmol})$. The flask was evacuated under vacuum and flushed with dry nitrogen three times. $100 \mathrm{~mL}$ of THF was then added. The mixture was cooled to $0{ }^{\circ} \mathrm{C}$ with an ice bath. $3.79 \mathrm{~g}(20 \mathrm{mmol}, 2.2 \mathrm{~mL})$ of $\mathrm{TiCl}_{4}$ was added dropwise by a syringe. The mixture was then stirred for $0.5 \mathrm{~h}$ at room temperature and refluxed for $24 \mathrm{~h}$. The reaction was quenched with $10 \%$ aqueous $\mathrm{K}_{2} \mathrm{CO}_{3}$ solution and filtered. The filtrate was extracted with THF three times. The organic layer was washed with water and dried over $\mathrm{Na}_{2} \mathrm{SO}_{4}$. After solvent evaporation, the crude product was purified by silica gel column chromatography us ing petroleum ether as eluent. White solid of 2 was isolated in 65\% yield. ${ }^{1} \mathrm{H}$ NMR (400 MHz, $\mathrm{CDCl}_{3}$ ), $\delta$ (TMS, ppm): 7.29- 7.20 (m, 4H), 7.17 -7.09 
(m, 6H), 7.03 - 6.96 (m, 4H), 6.91 - 6.85 (m, 4H). ${ }^{13} \mathrm{C}$ NMR (100 MHz, $\left.\mathrm{CDCl}_{3}\right), \delta(\mathrm{ppm}):$ 142.92, 142.82, 142.38, 142.29, 140.28, 132.89, 132.87, 131.21, 131.10, 130.90, 128.02, 127.82, 126.94, 126.84, 120.79, 120.66.

\section{1,2-diphe nyl-1,2-bis(4-vinylphenyl)e thane (DBVE)}

To a $250 \mathrm{~mL}$ two-necked round-bottom flask were added 2 (1.45 g, $3 \mathrm{mmol}$ ), potassium vinyltrifluoroborate $(0.884 \mathrm{~g}, 6.6 \mathrm{mmol})$, palladium acetate $(13.4 \mathrm{mg}, 0.06 \mathrm{mmol})$, triphenylphosphine $\left(\mathrm{PPh}_{3}, 47 \mathrm{mg}, 0.18 \mathrm{mmol}\right)$, caesium carbonate $\left(\mathrm{Cs}_{2} \mathrm{CO}_{3}, 2.93 \mathrm{~g}, 9 \mathrm{mmol}\right)$. The tube was evacuated under vacuum and then flushed with dry nitrogen three times. THF and water (50 mL, $9 / 1, \mathrm{v} / \mathrm{v}) \mathrm{was}$ injected into the flask under nitrogen. After stirring for $48 \mathrm{~h}$ at $90^{\circ} \mathrm{C}$, the mixture was cooled to room temperature and was filtered to remove the insoluble salt. The filtrates were reduced to dryness under reduced pressure. The crude product was purified by column chromatography using petroleum ether as the eluent and then was recrystallized in methanol. DBVE was obtained as white solid in 70.2\% yield. ${ }^{1} \mathrm{H}$ NMR (400 MHz, $\mathrm{CDCl}_{3}$ ), $\delta$ (TMS, ppm): 7.23 - 6.96 (m, 18H), 6.71 - 6.58 (m, 2H), 5.69 (ddd, $J=17.6,6.0,0.8 \mathrm{~Hz}, 2 \mathrm{H}$, cis-vinyl), 5.21 (ddd, $J=10.9,4.3,0.7 \mathrm{~Hz}, 2 \mathrm{H}$, trans-vinyl). ${ }^{13} \mathrm{C}$ NMR (100 $\left.\mathrm{MHz}, \mathrm{CDCl}_{3}\right), \delta$ (ppm): 143.69, 143.67, 143.39, 143.37, 140.69, 136.59, 135.61, $135.53\left(-\mathrm{CH}=\mathrm{CH}_{2}\right), 131.56,131.54,131.41$, 131.39, 127.79, 127.67, 126.55, 126.49, 125.66, 125.54, 113.54, $113.49\left(-\mathrm{CH}=\mathrm{CH}_{2}\right)$. HRMS (ESI positive): $[\mathrm{M}+\mathrm{H}]^{+}$calc'd for C30H25 m/z 385.1956, found 385.1942. IR bands: $1625 \mathrm{~cm}^{-1}$, $-\mathrm{C}=\mathrm{C}$ - double bond stretch, 991 and $910 \mathrm{~cm}^{-1}, \mathrm{C}-\mathrm{H}$ bend of monosubstituted alkene $-\mathrm{CH}=\mathrm{CH}_{2}$.

\section{Synthesis of DDB V}

\section{(2,2-dibromoethene-1,1-diyl)dibenzene (4)}

Into a $250 \mathrm{~mL}$ two-necked round-bottom flask with a reflux condenser were placed benzophenone (3) (3.64 g, $20 \mathrm{mmol}$ ) of, triphenylphosphine $\left(\mathrm{PPh}_{3}, 17.53 \mathrm{~g}, 80 \mathrm{mmol}\right)$, carbon tetrabromide $\left(\mathrm{CBr}_{4}, 13.27 \mathrm{~g}\right.$, $40 \mathrm{mmol}$ ). The flask was evacuated under vacuum and flushed with dry nitrogen three times. $100 \mathrm{~mL}$ of toluene was then added. The mixture was refluxed for $72 \mathrm{~h}$. After cooled down to room temperature, the mixture was filtered to remove the insoluble salt and washed with toluene three times. The filtrates were reduced to dryness under reduced pressure. The crude product was purified by silica gel column chromatography using petroleum ether as eluent. White solid of 4 was isolated in $49 \%$ yield. ${ }^{1} \mathrm{H}$ NMR (400 MHz, $\mathrm{CDCl}_{3}$ ), $\delta$ (TMS, ppm): 7.38 - 7.22 (m, 10H). ${ }^{13} \mathrm{C}$ NMR (100 MHz, $\mathrm{CDCl}_{3}$ ), $\delta$ (ppm):147.89, 141.42, 128.80, 128.40, 128.04, 90.37. 


\section{4,4'-(2,2-diphenylethe ne-1,1-diyl)bis(vinylbe nze ne) (DDBV)}

To a $250 \mathrm{~mL}$ two-necked round-bottom flask were added 4 (2.03 g, $6 \mathrm{mmol}$ ), 4-vinylphenylboronic acid (1.94 g, $13.2 \mathrm{mmol}$ ), palladium acetate (26.8 mg, $0.12 \mathrm{mmol}$ ), tetrabutylammonium bromide (TBAB, $192 \mathrm{mg}, 0.6 \mathrm{mmol})$, potassium carbonate $\left(\mathrm{K}_{2} \mathrm{CO}_{3}, 1.656 \mathrm{~g}, 12 \mathrm{mmol}\right)$. The tube was evacuated under vacuum and then flushed with dry nitrogen three times. The mixture solvent of toluene/ethanol/water (80 $\mathrm{mL}, 6 / 1 / 1, \mathrm{v} / \mathrm{v}$ ) was injected into the flask under nitrogen. After stirring for $48 \mathrm{~h}$ at $90{ }^{\circ} \mathrm{C}$, the mixture was cooled to room temperature and was filtered to remove the insoluble salt. The filtrates were reduced to dryness under reduced pressure. The crude product was purified by column chromatography using petroleum ether as the eluent and then was recrystallized in methanol. DDBV was obtained as white solid in 53.6\% yield. ${ }^{1} \mathrm{H}$ NMR (400 MHz, $\mathrm{CDCl}_{3}$ ), $\delta$ (TMS, ppm): 7.19 - 7.06 (m, 10H), 7.07 - 7.00 (m, 4H), 7.00 - 6.94 (m, 4H), 6.62 (dd, $J=17.6,10.9$ Hz, 2H), 5.67 (dd, $J=17.6,0.9 \mathrm{~Hz}, 2 \mathrm{H}$, cis-vinyl), 5.18 (dd, $J=10.9,0.8 \mathrm{~Hz}, 2 \mathrm{H}$, trans-vinyl). ${ }^{13} \mathrm{C} \mathrm{NMR}\left(100 \mathrm{MHz}, \mathrm{CDCl}_{3}\right), \delta$ (ppm): 143.73, 143.33, 141.15, 140.21, 136.58, 135.57(- $\left.\mathrm{CH}=\mathrm{CH}_{2}\right), 131.60,131.35,127.75,126.50,125.57,113.51\left(-\mathrm{CH}=\mathrm{CH}_{2}\right)$. HRMS (ESI positive): $[\mathrm{M}+\mathrm{H}]^{+}$calc'd for C30H25 m/z 385.1956, found 385.1952. IR bands: $1625 \mathrm{~cm}^{-1}$, $-\mathrm{C}=\mathrm{C}$ - double bond stretch, 991 and $910 \mathrm{~cm}^{-1}, \mathrm{C}-\mathrm{H}$ bend of monosubstituted alkene $-\mathrm{CH}=\mathrm{CH}_{2}$.

\section{Synthes is of Flu}

\section{2,7-divinyl-9,9-di-n-octylfluorene (Flu)}

To a $250 \mathrm{~mL}$ two-necked round-bottom flask were added 2,7-dibromo-9,9-di-n-octylfluorene (5, 3.32 g, $6 \mathrm{mmol})$, potassium vinyltrifluoroborate (1.768 g, $13.2 \mathrm{mmol})$, palladium acetate (27 mg, $0.12 \mathrm{mmol})$, triphenylphosphine $\left(\mathrm{PPh}_{3}, 94 \mathrm{mg}, 0.36 \mathrm{mmol}\right)$, caesium carbonate $\left(\mathrm{Cs}_{2} \mathrm{CO}_{3}, 5.86 \mathrm{~g}, 18 \mathrm{mmol}\right)$. The tube was evacuated under vacuum and then flushed with dry nitrogen three times. THF and water (50 mL, 9/1, $\mathrm{v} / \mathrm{v}$ ) was injected into the flask under nitrogen. After stirring for $48 \mathrm{~h}$ at $90^{\circ} \mathrm{C}$, the mixture was cooled to room temperature and was filtered to remove the insoluble salt. The filtrates were reduced to dryness under reduced pressure. The crude product was purified by column chromatography using petroleum ether as the eluent. Flu was obtained as white solid in $75.3 \%$ yield. ${ }^{1} \mathrm{H}$ NMR (400 MHz, $\left.\mathrm{CDCl}_{3}\right), \delta(\mathrm{TMS}$, ppm):7.63 (t, $J=8.7$ Hz, 2H), 7.47 - 7.33 (m, 4H), 6.83 (dd, $J=17.6,10.9$ Hz, 2H), 5.82 (d, $J=17.6$ Hz, 2H, cis-vinyl), 5.28 (d, $J=10.9 \mathrm{~Hz}, 2 \mathrm{H}$, trans-vinyl), 2.05 - 1.87 (m, 4H), 1.31 - 0.99 (m, 20H), 0.84 (t, $J$ $=7.1 \mathrm{~Hz}, 6 \mathrm{H}), 0.66$ (d, $J=7.3 \mathrm{~Hz}, 4 \mathrm{H}) .{ }^{13} \mathrm{C}$ NMR $\left(100 \mathrm{MHz}, \mathrm{CDCl}_{3}\right), \delta(\mathrm{ppm}): 151.38,140.74,137.41$, 136.46(- $\left.\mathrm{CH}=\mathrm{CH}_{2}\right), 125.24,120.51,119.69,113.00\left(-\mathrm{CH}=\mathrm{CH}_{2}\right), 54.92,40.40,31.80,30.02,29.23,29.19$, 23.70, 22.61, 14.09. HRMS (ESI positive): $[\mathrm{M}+\mathrm{H}]^{+}$calc'd for C33H47 m/z 443.3678, found 443.3669 . 
Synthesis of Ben

\section{1,4-dihexyl-2,5-divinylbenzene (Ben)}

To a $250 \mathrm{~mL}$ two-necked round-bottom flask were added 1,4-dibromo-2,5-dihexylbenzene (6, $2.41 \mathrm{~g}$, $6 \mathrm{mmol}$ ), potassium vinyltrifluoroborate (1.768 g, $13.2 \mathrm{mmol}$ ), palladium acetate (27 mg, $0.12 \mathrm{mmol}$ ), triphenylphosphine $\left(\mathrm{PPh}_{3}, 94 \mathrm{mg}, 0.36 \mathrm{mmol}\right)$, caesium carbonate $\left(\mathrm{Cs}_{2} \mathrm{CO}_{3}, 5.86 \mathrm{~g}, 18 \mathrm{mmol}\right)$. The tube was evacuated under vacuum and then flushed with dry nitrogen three times. THF and water $(50 \mathrm{~mL}, 9 / 1$, $\mathrm{v} / \mathrm{v}$ ) was injected into the flask under nitrogen. After stirring for $48 \mathrm{~h}$ at $90{ }^{\circ} \mathrm{C}$, the mixture was cooled to room temperature and was filtered to remove the insoluble salt. The filtrates were reduced to dryness under reduced pressure. The crude product was purified by column chromatography using petroleum ether as the eluent. Ben was obtained as colorless liquid in 56\% yield. ${ }^{1} \mathrm{H}$ NMR (400 $\mathrm{MHz}, \mathrm{CDCl}_{3}$ ), $\delta$ (TMS, ppm): 7.33 (s, 2H), 7.13 - 6.90 (m, 2H), 5.70 (d, $J=17.4$ Hz, 2H, cis-vinyl), 5.31 (d, $J=11.0 \mathrm{~Hz}$, 2H, trans-vinyl), 2.68 (dd, $J=23.8,15.8 \mathrm{~Hz}, 4 \mathrm{H}), 1.69$ - 1.51 (m, 4H), $1.51-1.23(\mathrm{~m}, 12 \mathrm{H}), 0.95$ (dd, $J=$ 6.8, 6.2 Hz, 6H). ${ }^{13} \mathrm{C}$ NMR (100 MHz, $\left.\mathrm{CDCl}_{3}\right), \delta(\mathrm{ppm}): 138.03,135.63\left(-\mathrm{CH} \mathrm{CH}_{2}\right), 134.44,126.61$, $114.66\left(-\mathrm{CH}=\mathrm{CH}_{2}\right), 33.14,31.78,31.35,29.41,22.70,14.15$. HRMS (ESI positive): $[\mathrm{M}+\mathrm{H}]^{+}$calc'd for C22H35 m/z 299.2739, found 299.2732. 


\section{Synthes is of polymers}

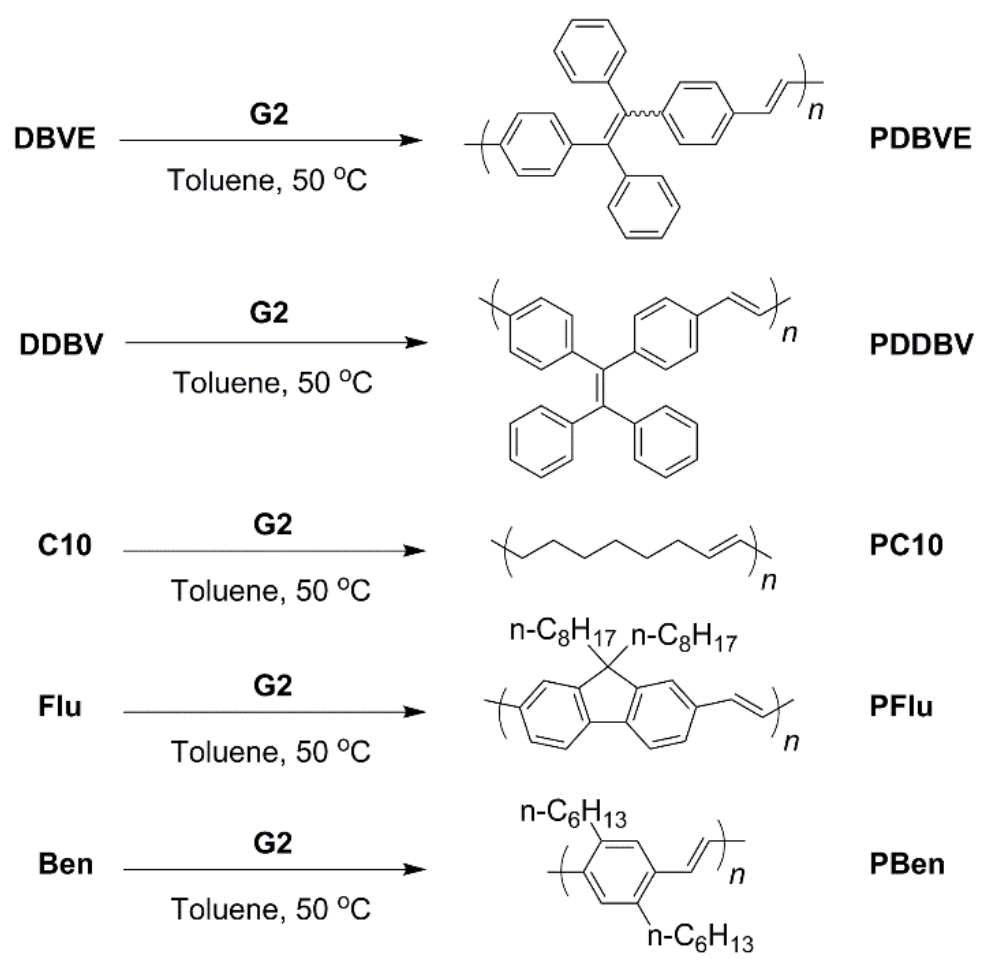

Scheme S2. Homopolymerization of ADMET monomers.

General polymerization procedure: Synthes is of PDBVE. As an example, polymerizations of DBVE were performed under different conditions, such as polymerization time, the catalysts, solvents, monomer ratio, and temperature. As shown in Table S1, No. 4 gave the highest molecular weight of the polymer. This condition was then chosen as the standard one for all polymerizations. Typically, toluene (0.4 mL), DBVE (77 mg, $0.2 \mathrm{mmol}$ ), and Grubbs catalyst $2^{\text {nd }}$ generation [Ru2, $1.7 \mathrm{mg}, 2 \mu \mathrm{mol}$ ] were charged into a sealed Schlenk-type tube in the drybox. The tube was then placed into a liquid nitrogen bath. Three cycles of freeze-pump-thaw were applied to remove ethylene byproduct, which followed the method reported by Nomura et al. ${ }^{1}$ The tube was then placed into an oil bath preheated at $50{ }^{\circ} \mathrm{C}$ and the mixture was stirred for prescribed time. During the reaction, the mixture was placed into a liquid nitrogen bath with a certain period (every $10 \mathrm{~min}$ at the initial $1 \mathrm{~h}$, then every $30 \mathrm{~min}$ for $3 \mathrm{~h}$, and then every $12 \mathrm{~h}$ ) to remove ethylene from the reaction medium by opening the valve connected to the vacuum line and then placed into the oil bath to continue the reaction. Generally, the mixture became viscous and yellow precipitates appeared after $2 \mathrm{~h}$. After $48 \mathrm{~h}, 10 \mathrm{~mL}$ of toluene was added to dilute the mixture. The polymerization was quenched by adding ethyl vinyl ether $(0.5 \mathrm{~mL})$ and the mixture was stirred for $1 \mathrm{hr}$ for completion. The resultant solution was added dropwise to a mixture of methanol $(150 \mathrm{~mL})$ under stirring, affording yellow precipitates. The polymer was collected by filtration and was then dried in a vacuum oven. A yellow solid 
was obtained in $80 \%$ yield. ${ }^{1} \mathrm{H}$ NMR (400 $\mathrm{MHz}, \mathrm{CDCl}_{3}, \delta$, ppm): Soluble part in $\mathrm{CDCl}_{3}, 7.35$ - $6.83(-\mathrm{ArH}$ and trans $-\mathrm{CH}=\mathrm{CH}-$ ), 6.75 (dd, $J=17.6,10.9 \mathrm{~Hz},-\mathrm{CH}=\mathrm{CH}_{2}$ at the chain ends), 5.78 (d, $J=17.6 \mathrm{~Hz}$, cis- $H$ of $-\mathrm{CH}=\mathrm{CH}_{2}$ at the chain ends), 5.27 (d, $J=10.9 \mathrm{~Hz}$, trans- $\mathrm{H}$ of- $\mathrm{CH}=\mathrm{CH}_{2}$ at the chain ends). IR bands: $1597 \mathrm{~cm}^{-1}$, $-\mathrm{C}=\mathrm{C}$ - double bond stretch, $961 \mathrm{~cm}^{-1}, \mathrm{C}-\mathrm{H}$ bend of trans-CH=CH- .

Table S1. Polymerization conditions for DBVE monomer ${ }^{a}$

\begin{tabular}{cccccccccc}
\hline No & $\begin{array}{c}\text { Time } \\
(\mathrm{h})\end{array}$ & Catalyst $^{b}$ & Solvent & $\begin{array}{c}{[\mathrm{M}]^{c}} \\
(\mathrm{~mol} / \mathrm{L})\end{array}$ & $\begin{array}{c}\mathrm{T} \\
\left({ }^{\circ} \mathrm{C}\right)\end{array}$ & Yield & $M_{\mathrm{n}}{ }^{d}$ & $M_{\mathrm{w}}{ }^{d}$ & PDI $^{d}$ \\
\hline 1 & 72 & $\mathbf{G 1}$ & Toluene & 0.5 & 50 & 0 & $-^{e}$ & $-^{e}$ & $-^{e}$ \\
2 & 72 & $\mathbf{G} 2$ & Toluene & 0.5 & 80 & $70 \%$ & 6100 & 11000 & 1.8 \\
3 & 48 & $\mathbf{G} 2$ & $\mathrm{TCB}^{f}$ & 0.5 & 60 & $74 \%$ & 18200 & 26200 & 1.4 \\
4 & 48 & $\mathbf{G 2}$ & Toluene & 0.5 & 50 & $80 \%$ & 15100 & 28300 & 1.9 \\
5 & 24 & $\mathbf{G} 2$ & Toluene & 0.25 & 50 & $90 \%$ & 9900 & 19800 & 2.0 \\
6 & 24 & $\mathbf{G 3}$ & Toluene & 0.25 & 50 & $30 \%$ & 4300 & 4900 & 1.1 \\
7 & 48 & $\mathbf{G 3}$ & Toluene & 0.25 & 50 & $38 \%$ & $2300^{g}$ & $2800^{g}$ & $1.2^{g}$ \\
\hline
\end{tabular}

${ }^{a}$ The molar ratio of the monomer to the catalyst ([M]/[Ru]) was $100 .{ }^{b} \mathbf{G 1}$, Grubbs catalyst $1^{\text {st }}$ generation; G2, Grubbs catalyst $2^{\text {nd }}$ generation; G3, Grubbs catalyst $3^{\text {rd }}$ generation. ${ }^{c}$ Monomer concentration. ${ }^{d}$ GPC measurement of the soluble part of the sample performed in THF at $40{ }^{\circ} \mathrm{C}$. ${ }^{e}$ No polymer yielded. ${ }^{f}$ 1,2,4-Trichlorobenzene. ${ }^{g}$ Determined in TCB at $150{ }^{\circ} \mathrm{C}$. 


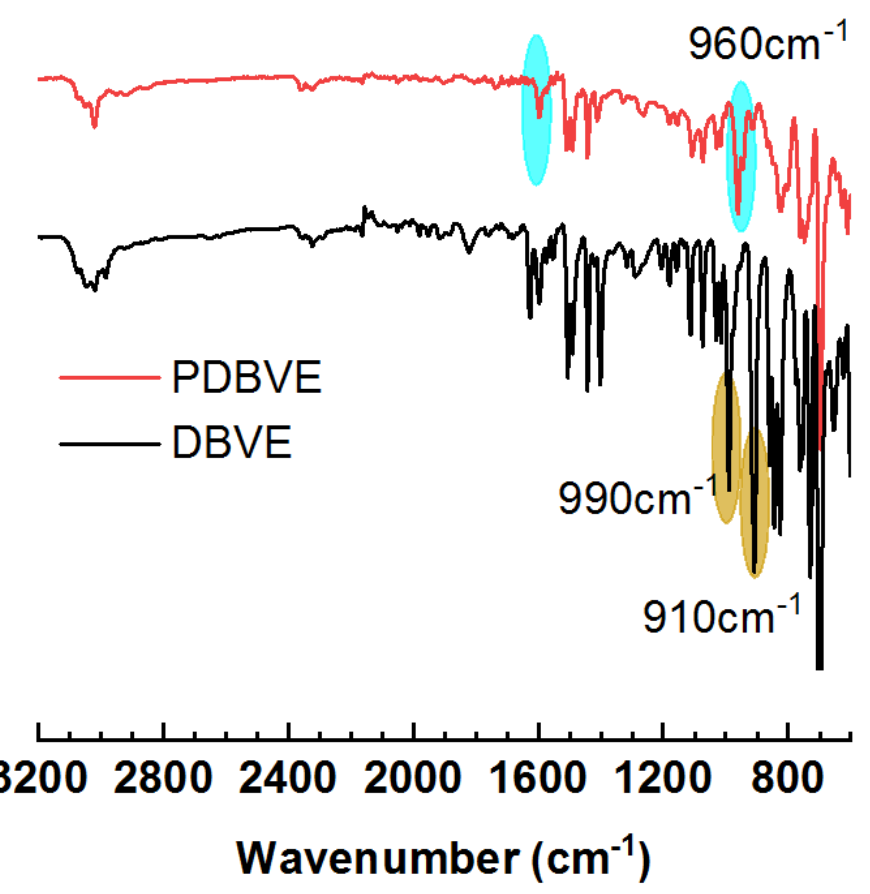

Figure S1. IR spectra of DBVE and PDBVE.

PDDBV. Insoluble light yellow solid, yield 78\%. IR bands:1597 $\mathrm{cm}^{-1},-\mathrm{C}=\mathrm{C}$ - double bond stretch, 965 $\mathrm{cm}^{-1}, \mathrm{C}-\mathrm{H}$ bend of trans- $\mathrm{CH}=\mathrm{CH}-$.

PC10. Thick oil-like polymer. Trace amount, impossible to get accurate yield of the sticky polymer. ${ }^{1} \mathrm{H}$ NMR (400 MHz, $\left.\mathrm{CDCl}_{3}, \delta, \mathrm{ppm}\right): 5.52$ - 5.29 (m, trans - $\left.\mathrm{CH}=\mathrm{CH}-, 2 \mathrm{H}\right), 2.11-1.88$ (m, $-\mathrm{CH}_{2} \mathrm{CH}=\mathrm{CHCH}_{2^{-}}$, 4H), 1.46 - 1.17 (m, -( $\left.\left(\mathrm{CH}_{2}\right)_{4}, 8 \mathrm{H}\right)$.

PFlu. Yellow solid, yield 91\%. ${ }^{1} \mathrm{H}$ NMR (400 MHz, $\mathrm{C}_{2} \mathrm{D}_{2} \mathrm{Cl}_{4}, \delta$, ppm): 8.22 - 6.96 (m, -ArH and trans - $\mathrm{CH}=\mathrm{CH}$-), 2.42 - 1.85 (br, $\left.-\mathrm{CH}_{2}\left(\mathrm{CH}_{2}\right)_{5} \mathrm{CH}_{2} \mathrm{CH}_{3}\right), 1.48$ - 0.94 (m, $\left.-\mathrm{CH}_{2}\left(\mathrm{CH}_{2}\right)_{5} \mathrm{CH}_{2} \mathrm{CH}_{3}\right), 0.93$ - 0.52 (m, $\left.-\mathrm{CH}_{2}\left(\mathrm{CH}_{2}\right)_{5} \mathrm{CH}_{2} \mathrm{CH}_{3}\right)$. IR bands: $1604 \mathrm{~cm}^{-1}$, $-\mathrm{C}=\mathrm{C}$ - double bond stretch, $960 \mathrm{~cm}^{-1}, \mathrm{C}-\mathrm{H}$ bend of trans- $\mathrm{CH}=\mathrm{CH}-$.

PBen. Insoluble yellow solid, yield 75\%. IR bands:1599 $\mathrm{cm}^{-1},-\mathrm{C}=\mathrm{C}$ - double bond stretch, $963 \mathrm{~cm}^{-1}, C-H$ bend of trans- $\mathrm{CH}=\mathrm{CH}-$. 

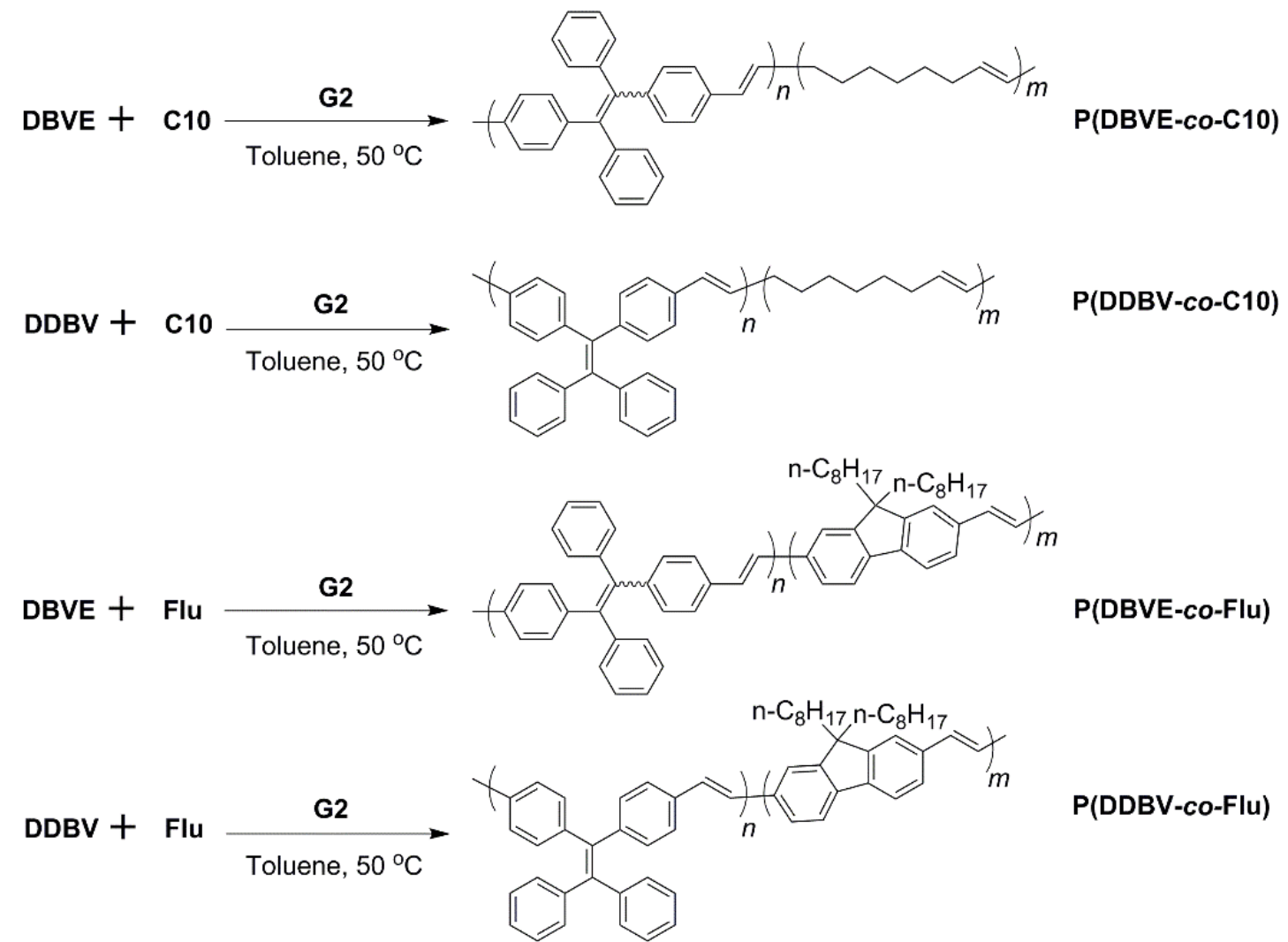

P(DDBV-co-Flu)
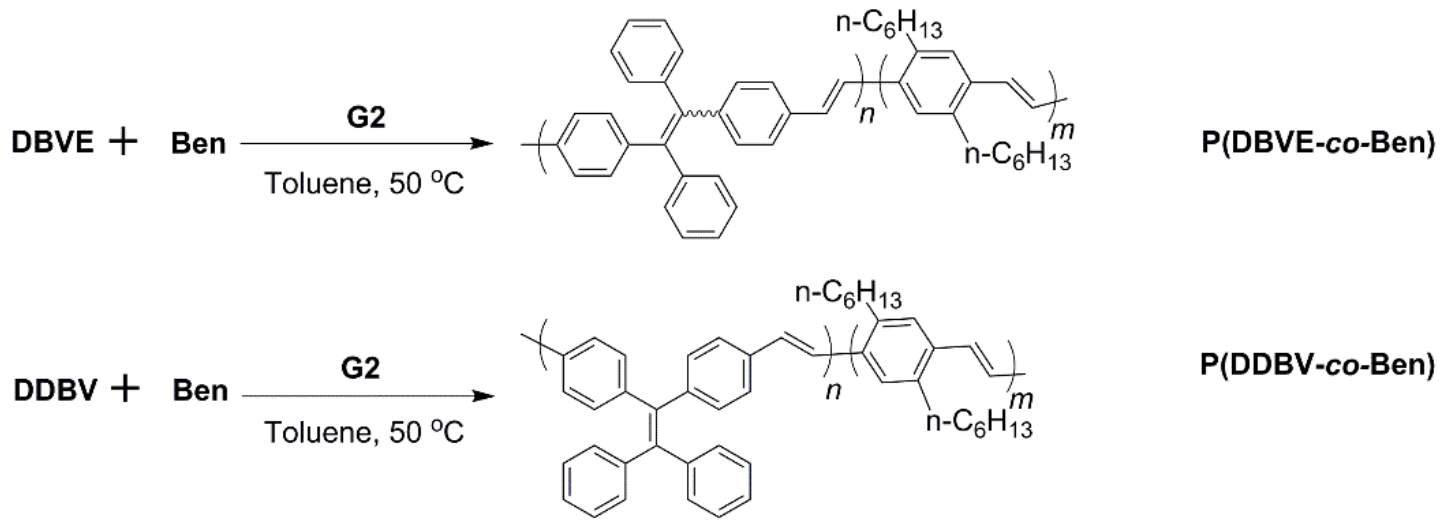

Scheme S3. Copolymerization of ADMET monomers.

General copolymerization procedure: In a typical copolymerization, toluene $(0.8 \mathrm{~mL})$, the TPE-containing monomer (77 mg, $0.2 \mathrm{mmol})$, the co-monomer $(0.2 \mathrm{mmol})$ and Grubbs catalyst $2^{\text {nd }}$ generation (Ru2, $3.5 \mathrm{mg}, 4 \mu \mathrm{mol}$ ) were charged into a sealed Schlenk-type tube in the drybox. The polymerization procedure follows that of homopolymers as above.

P(DB VE-co-C10). Yellow solid, yield 87\%. ${ }^{1} \mathrm{H}$ NMR (400 MHz, $\mathrm{C}_{2} \mathrm{D}_{2} \mathrm{Cl}_{4}, \delta$, ppm): 7.78 - 6.54 (br, -ArH and trans $-\mathrm{ArCH}=\mathrm{CHAr}-$ ), 6.29 (br, trans $\left.-\mathrm{ArCH}=\mathrm{CH}\left(\mathrm{CH}_{2}\right)_{6}{ }^{-}\right), 6.22$ (br, trans $\left.-\mathrm{ArCH}=\mathrm{CH}\left(\mathrm{CH}_{2}\right)_{6}{ }^{-}\right), 5.39$ (br, trans $\left.-\left(\mathrm{CH}_{2}\right)_{6} \mathrm{CH}=\mathrm{CH}\left(\mathrm{CH}_{2}\right)_{6^{-}}\right), 2.47$ - 1.85 (m,- $\left.\mathrm{CH}=\mathrm{CH}\left(\mathrm{CH}_{2}\right)_{2}\left(\mathrm{CH}_{2}\right)_{4^{-}}\right), \quad 1.75$ - $1.12 \quad$ (m, 
$\left.-\mathrm{CH}=\mathrm{CH}\left(\mathrm{CH}_{2}\right)_{2}\left(\mathrm{CH}_{2}\right)_{4^{-}}\right)$. IR bands:1599 $\mathrm{cm}^{-1}$, - $\mathrm{C}=\mathrm{C}$ - double bond stretch, $963 \mathrm{~cm}^{-1}, \mathrm{C}-\mathrm{H}$ bend of trans- $\mathrm{CH}=\mathrm{CH}-$.

P(DDB V-co-C10). Yellow solid, yield 87\%. ${ }^{1} \mathrm{H}$ NMR (400 MHz, $\mathrm{C}_{2} \mathrm{D}_{2} \mathrm{Cl}_{4}, \delta$, ppm): soluble part in $\mathrm{C}_{2} \mathrm{D}_{2} \mathrm{Cl}_{4}, 7.43$ - 6.66 (br, -ArH and trans -ArCH=CHAr-), 6.28 (d, trans - $\left.\mathrm{ArCH}=\mathrm{CH}\left(\mathrm{CH}_{2}\right)_{6}{ }^{-}\right), 6.21$ (br, trans $\left.\quad-\mathrm{ArCH}=\mathrm{CH}\left(\mathrm{CH}_{2}\right)_{6}{ }^{-}\right), \quad 5.39 \quad$ (br, trans $\left.\quad-\left(\mathrm{CH}_{2}\right)_{6} \mathrm{CH}=\mathrm{CH}\left(\mathrm{CH}_{2}\right)_{6}{ }^{-}\right), \quad 2.31 \quad-\quad 1.75$ $\left(\mathrm{m},-\mathrm{CH}=\mathrm{CH}\left(\mathrm{CH}_{2}\right)_{2}\left(\mathrm{CH}_{2}\right)_{4}^{-}\right), 1.73-1.08\left(\mathrm{~m},-\mathrm{CH}=\mathrm{CH}\left(\mathrm{CH}_{2}\right)_{2}\left(\mathrm{CH}_{2}\right)_{4^{-}}\right)$. IR bands:1599 $\mathrm{cm}^{-1}$, -C=C- double bond stretch, $963 \mathrm{~cm}^{-1}, \mathrm{C}-\mathrm{H}$ bend of trans- $\mathrm{CH}=\mathrm{CH}-$.

P(DB VE-co-Flu). Yellow solid, yield 90\%. ${ }^{1} \mathrm{H}$ NMR (400 MHz, $\mathrm{C}_{2} \mathrm{D}_{2} \mathrm{Cl}_{4}, \delta$, ppm): 8.16 - 6.74 (m, -ArH and trans -ArCH=CHAr-), $2.33-1.82$ (br, $-\mathrm{CH}_{2}\left(\mathrm{CH}_{2}\right)_{5} \mathrm{CH}_{2} \mathrm{CH}_{3}$ ), $1.40-0.91$ (br, $-\mathrm{CH}_{2}\left(\mathrm{CH}_{2}\right)_{5} \mathrm{CH}_{2} \mathrm{CH}_{3}$ ), $0.88-0.40$ (br, $\left.-\mathrm{CH}_{2}\left(\mathrm{CH}_{2}\right)_{5} \mathrm{CH}_{2} \mathrm{CH}_{3}\right)$. IR bands:1601 $\mathrm{cm}^{-1}$, -C=C- double bond stretch, $961 \mathrm{~cm}^{-1}, \mathrm{C}-\mathrm{H}$ bend of trans- $\mathrm{CH}=\mathrm{CH}-$.

P(DDB V-co-Flu). Yellow solid, yield 89\%. ${ }^{1} \mathrm{H}$ NMR (400 MHz, $\mathrm{C}_{2} \mathrm{D}_{2} \mathrm{Cl}_{4}, \delta$, ppm): 7.90 - 6.82 (m, -ArH and trans -ArCH=CHAr-), $2.23-1.81$ (br, $-\mathrm{CH}_{2}\left(\mathrm{CH}_{2}\right)_{5} \mathrm{CH}_{2} \mathrm{CH}_{3}$ ), 1.34 - 0.91 (br, $-\mathrm{CH}_{2}\left(\mathrm{CH}_{2}\right)_{5} \mathrm{CH}_{2} \mathrm{CH}_{3}$ ), $0.90-0.50$ (br, $\left.-\mathrm{CH}_{2}\left(\mathrm{CH}_{2}\right)_{5} \mathrm{CH}_{2} \mathrm{CH}_{3}\right)$. IR bands:1598 $\mathrm{cm}^{-1}$, -C=C- double bond stretch, $960 \mathrm{~cm}^{-1}, \mathrm{C}-\mathrm{H}$ bend of trans- $\mathrm{CH}=\mathrm{CH}-$.

P(DBVE-co-Ben). Yellow solid, yield 73.5\%. ${ }^{1} \mathrm{H}$ NMR (400 MHz, $\mathrm{C}_{2} \mathrm{D}_{2} \mathrm{Cl} 4$, $\delta$, ppm): 7.65 - 6.78 (m, -ArH and trans -ArCH=CHAr-), 2.74 (br, $\left.-\mathrm{CH}_{2} \mathrm{CH}_{2}\left(\mathrm{CH}_{2}\right)_{3} \mathrm{CH}_{3}\right), 1.80-1.53$ (br, $-\mathrm{CH}_{2} \mathrm{CH}_{2}\left(\mathrm{CH}_{2}\right)_{3} \mathrm{CH}_{3}$ ), 1.53 - 1.13 (br, $-\mathrm{CH}_{2} \mathrm{CH}_{2}\left(\mathrm{CH}_{2}\right)_{3} \mathrm{CH}_{3}$ ), 0.90 (br, $-\mathrm{CH}_{2} \mathrm{CH}_{2}\left(\mathrm{CH}_{2}\right)_{3} \mathrm{CH}_{3}$ ). IR bands:1598 cm ${ }^{-1}$, -C=C- double bond stretch, $961 \mathrm{~cm}^{-1}, \mathrm{C}-\mathrm{H}$ bend of trans- $\mathrm{CH}=\mathrm{CH}-$.

P(DDB V-co-Ben). Yellow solid, yield 80\%. ${ }^{1} \mathrm{H}$ NMR (400 MHz, $\mathrm{C}_{2} \mathrm{D}_{2} \mathrm{Cl}_{4}, \delta$, ppm): 7.67 - 6.80 (m, -ArH and trans -ArCH=CHAr-), 2.74 (br, $\left.-\mathrm{CH}_{2} \mathrm{CH}_{2}\left(\mathrm{CH}_{2}\right)_{3} \mathrm{CH}_{3}\right), 1.84-1.53$ (br, $\left.-\mathrm{CH}_{2} \mathrm{CH}_{2}\left(\mathrm{CH}_{2}\right)_{3} \mathrm{CH}_{3}\right), 1.53$ 1.13 (br, $-\mathrm{CH}_{2} \mathrm{CH}_{2}\left(\mathrm{CH}_{2}\right)_{3} \mathrm{CH}_{3}$ ), 0.90 (br, $-\mathrm{CH}_{2} \mathrm{CH}_{2}\left(\mathrm{CH}_{2}\right)_{3} \mathrm{CH}_{3}$ ). IR bands:1598 cm ${ }^{-1},-\mathrm{C}=\mathrm{C}$ - double bond stretch, $961 \mathrm{~cm}^{-1}, \mathrm{C}-\mathrm{H}$ bend of trans- $\mathrm{CH}=\mathrm{CH}-$. 


\section{Molecular we ights de termine d by GPC in THF}

GPC measurements were performed in 1,2,4-trichlorobenzene (TCB) at high temperature $\left(150{ }^{\circ} \mathrm{C}\right)$ for all the polymers. For polymers soluble in common organic solvents, GPC experiments were also carried out in THF at $40^{\circ} \mathrm{C}$. The molecular weights and polydispersity index (PDI) determined by two methods were similar.

Table S2. Molecular we ights determined in THF

\begin{tabular}{|c|c|c|c|}
\hline Polymer & $M_{\mathrm{n}}{ }^{a}$ & $M_{\mathrm{w}}{ }^{a}$ & $\mathrm{PDI}^{a}$ \\
\hline PDB VE & 15000 & 28000 & 1.9 \\
\hline P(DB VE-co-C10) & 7500 & 8400 & 1.2 \\
\hline P(DBVE-co-Flu) & 45300 & 90600 & 2.0 \\
\hline P(DB VE-co-Ben) & 9700 & 12700 & 1.3 \\
\hline PDDBV & $-{ }^{b}$ & $--^{b}$ & $-b$ \\
\hline $\mathbf{P}\left(\mathbf{D D B}\right.$ V-co-C10) ${ }^{c}$ & 7900 & 9150 & 1.2 \\
\hline P(DDB V-co-Flu) & 24500 & 46600 & 1.9 \\
\hline P(DDB V-co-Ben) & 9300 & 11800 & 1.3 \\
\hline PC10 & $-b$ & $-{ }^{b}$ & $--^{b}$ \\
\hline PFlu & 77000 & 153000 & 2.0 \\
\hline PBen & $-{ }^{b}$ & $-b$ & $--^{b}$ \\
\hline
\end{tabular}

\footnotetext{
${ }^{a}$ Molecular weights determined in THF at $40{ }^{\circ} \mathrm{C} .{ }^{b}$ Not determined. ${ }^{c}$ Soluble portion in THF.
} 


\section{Structural Characterization of DDB V-containing polymers}

(a)
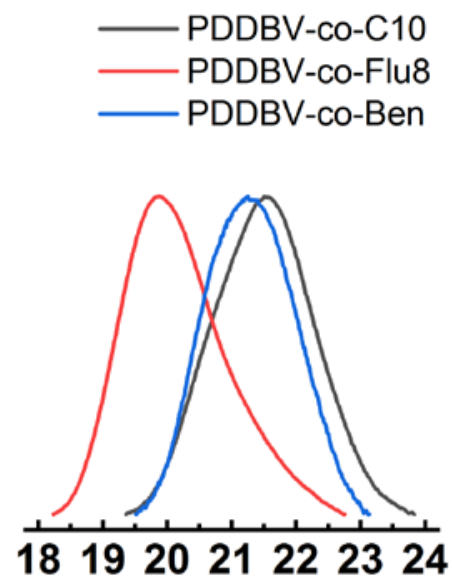

Elution time (min)

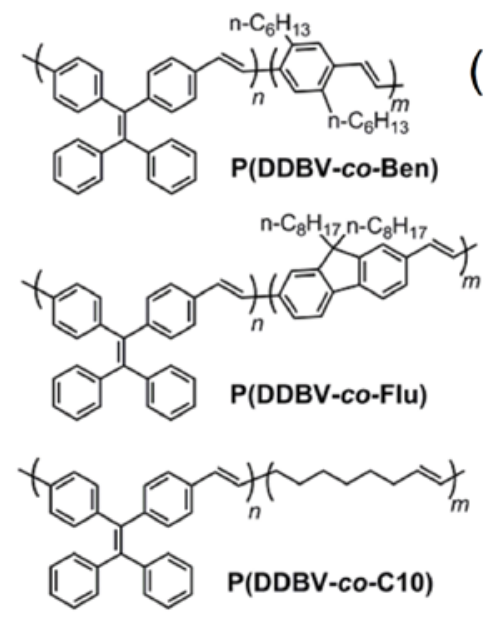

(b)

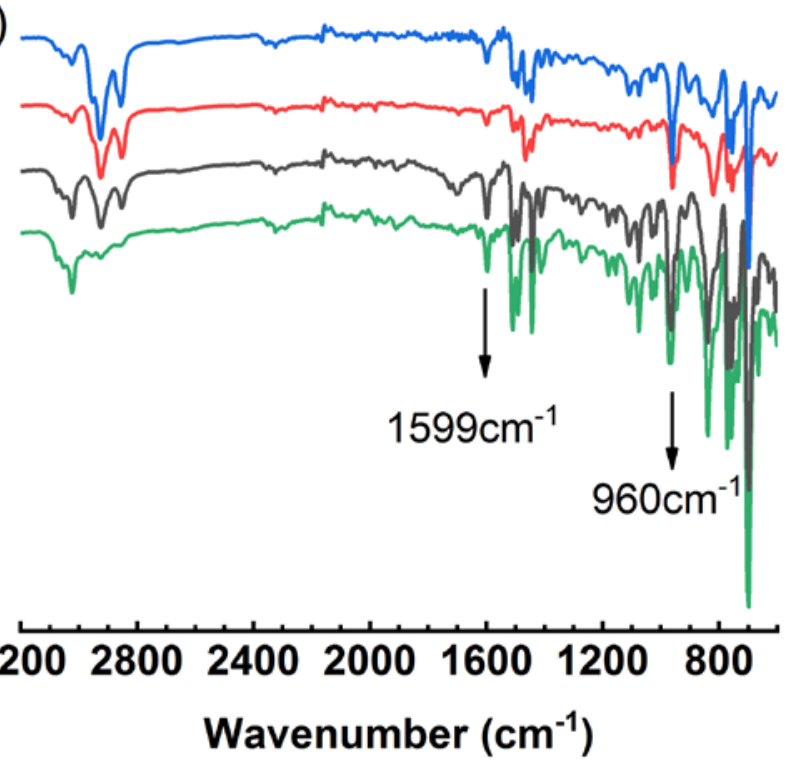

(c)

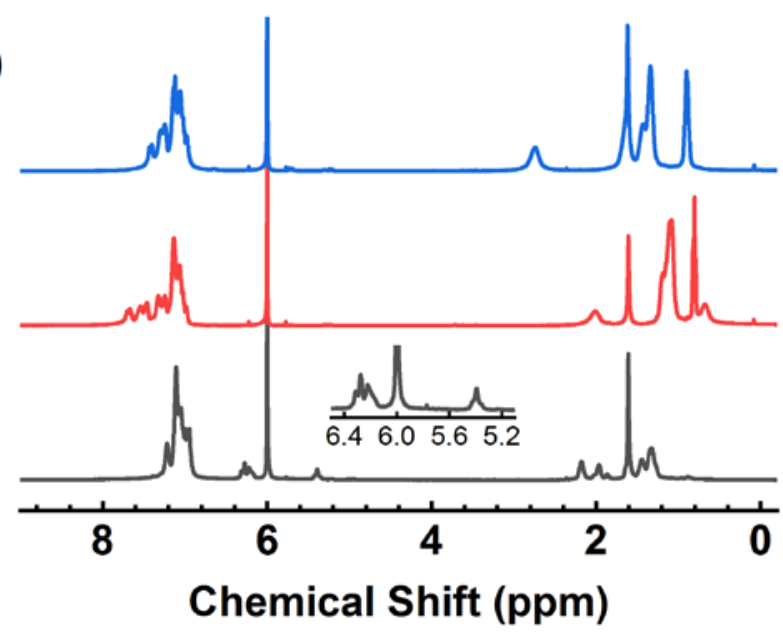

Figure S2. Characterization of DDBV-containing polymers: P(DDBV-co-C10) in grey line, P(DDB V-co-Flu) in red line, and P(DDB V-co-Ben) in blue line. (a) GPC curves of copolymers running in TCB at high temperature $150{ }^{\circ} \mathrm{C}$. (b) IR spectra of copolymers. The spectrum of PDDBV (green line) was also shown for comparison. (c) ${ }^{1} \mathrm{H}$ NMR spectra of copolymers in $\mathrm{C}_{2} \mathrm{D}_{2} \mathrm{Cl}_{4}$. Chemical shifts at 6.0 and $1.56 \mathrm{ppm}$ were ascribed to the solvent and $\mathrm{H}_{2} \mathrm{O}$, respectively. Insert plot highlights the proton resonances from the double bonds in C10-C10 and C10-DDBV diads in P(DDB V-co-C10). 


\section{Integration analys is of ${ }^{1} \mathrm{H}$ NMR spectra to de termine $\boldsymbol{f}_{\text {[TPE] }}$}

For Flu and Ben containing copolymers, similar analysis processes to that of PDDBV-co-C10 are applied. As an example, Figure S3 shows ${ }^{1} \mathrm{H}$ NMR spectrum of P(DDB V-co-Flu). Protons $a$ (4H) on C8 alkyl chains of Flu are used as the reference for integration. Resonances of protons on TPE (20H) and Flu $(8 \mathrm{H})$ moieties locating at 8.0-6.8 ppm are overlapped. Integrations of protons $a$, TPE, and Flu are denoted by $I_{\mathrm{a}}, I_{\mathrm{TPE}}$, and $I_{\mathrm{Flu}}$, respectively. Theoretically, $I_{\mathrm{Flu}}=2 I_{\mathrm{a}}$, Then $f_{[\mathrm{TPE}]}$ is written as:

$$
f_{\mathrm{TPE}}=\frac{\left(I_{\mathrm{TPE}}+I_{\mathrm{Flu}}-2 I_{\mathrm{a}}\right) / 20}{\left(I_{\mathrm{TPE}}+I_{\mathrm{Flu}}-2 I_{\mathrm{a}}\right) / 20+I_{\mathrm{a}} / 4}
$$

For $\mathbf{P}\left(\mathbf{D D B}\right.$ V-co-Flu), $f_{[\mathrm{TPE}]}$ is calculated as $51.0 \%$. Spectra of other polymers are shown in Part 14 of SI.

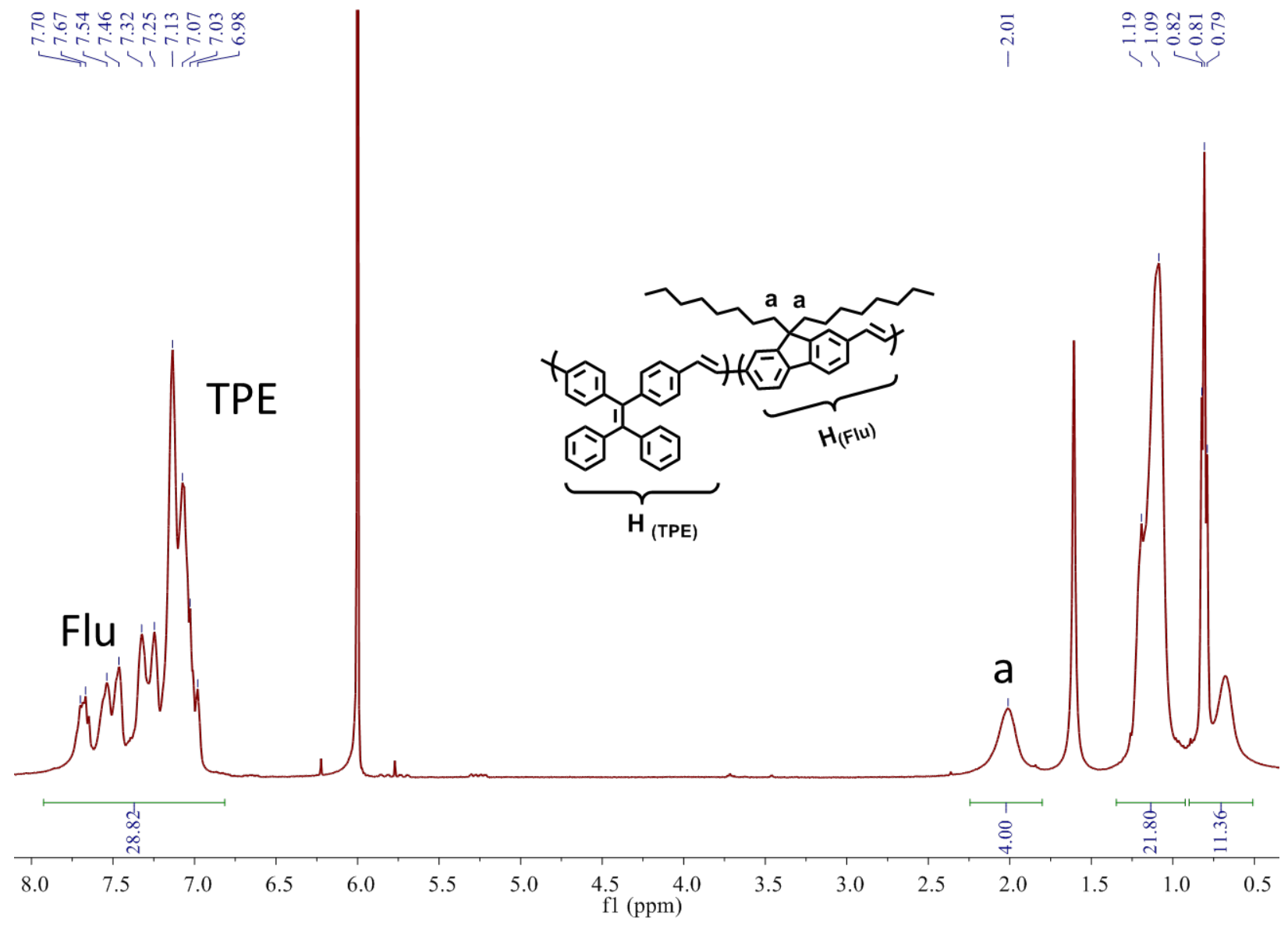

Figure S3. Integration analysis of ${ }^{1} \mathrm{H}$ NMR spectrum of $\mathbf{P ( D D B ~ V - c o - F l u ) . ~}$ 


\section{The rmal measurements}

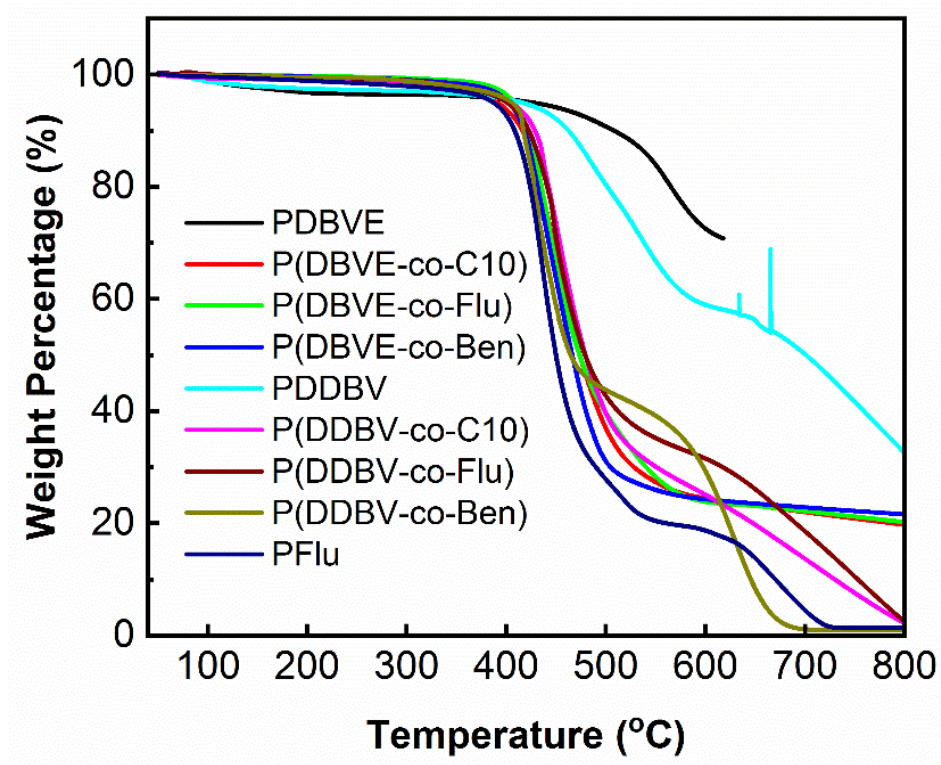

Figure S4. TGA curves of the polymers. The signal noises between 600 and $700{ }^{\circ} \mathrm{C}$ on the curve of PDDBV were due to the gas flow fluctuation during the measurement.

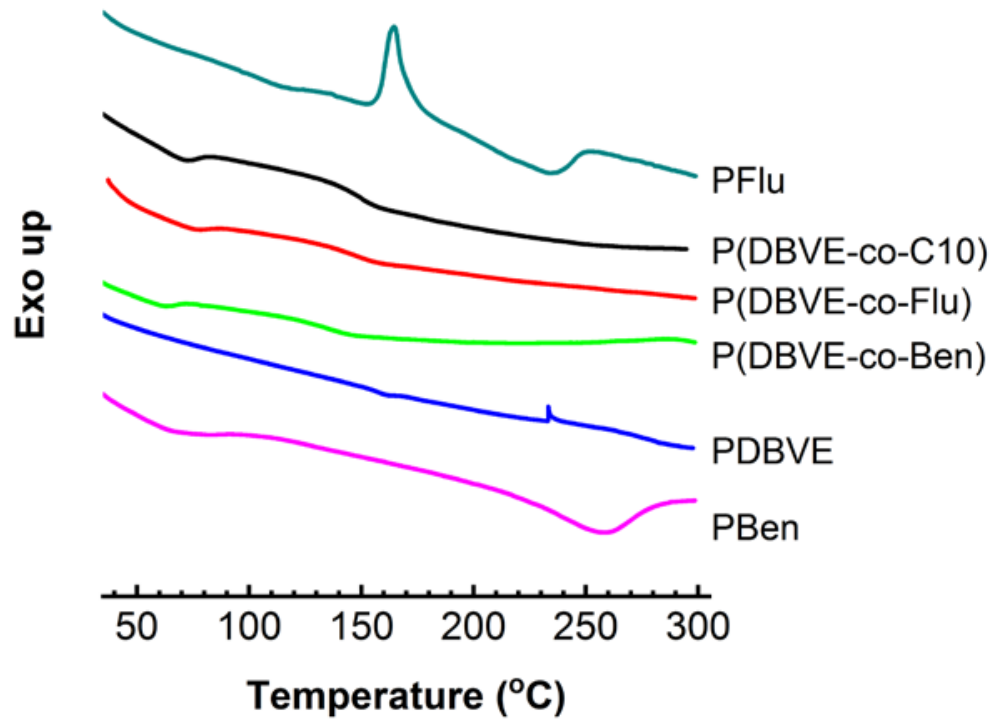

Figure S5. DSC curves of DBVE containing polymers recorded at $10^{\circ} \mathrm{C} / \mathrm{min}$ during the second heating process. 


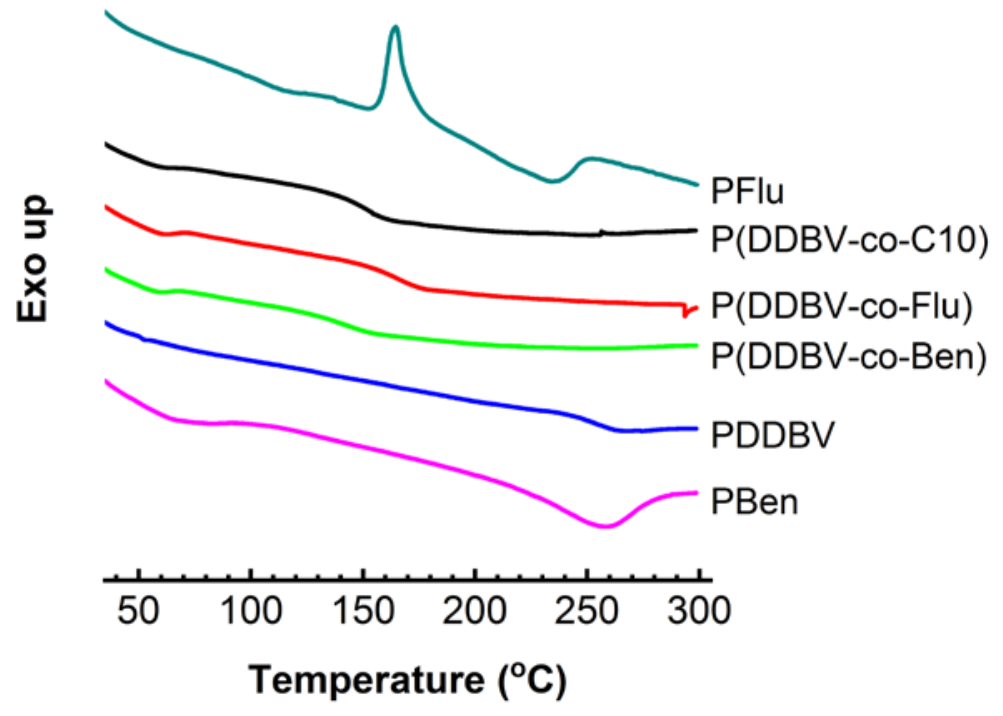

Figure S6. DSC curves of DDBV containing polymers recorded at $10^{\circ} \mathrm{C} / \mathrm{min}$ during the second heating process. 
7. Optical properties of ADMET monomers and homopolymers

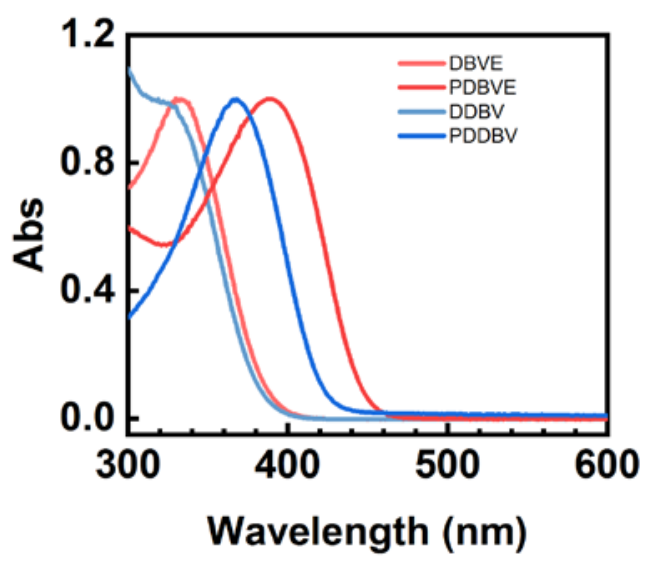

Figure S7. Normalized absorption spectra of DBVE, DDBV, PDBVE, and PDDBV in THF solutions. For PDB VE and PDDBV, measurements were carried out by using the soluble portions of the samples in THF.

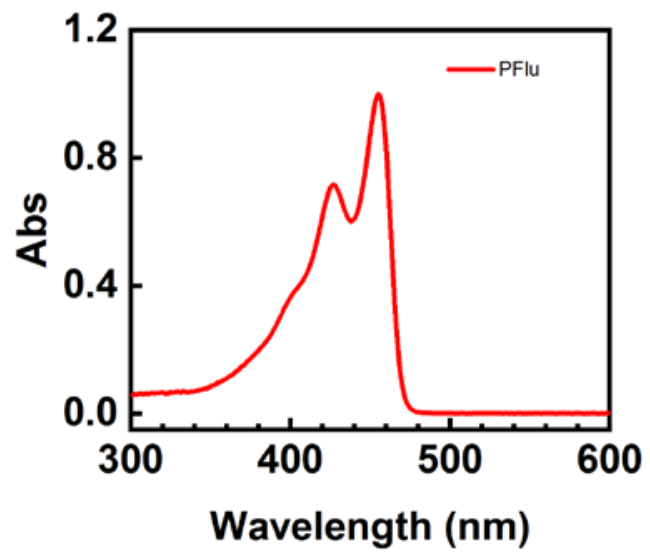

Figure S8. Absorption spectrum of PFlu in THF solution, which displayed three absorption bands $\left(\lambda_{\mathrm{abs}}=\right.$ 455 , 427, and $400 \mathrm{~nm}$ ) attributed to $\pi-\pi^{*}$ transitions of $0-0,0-1$, and $0-2$ transitions, respectively. 

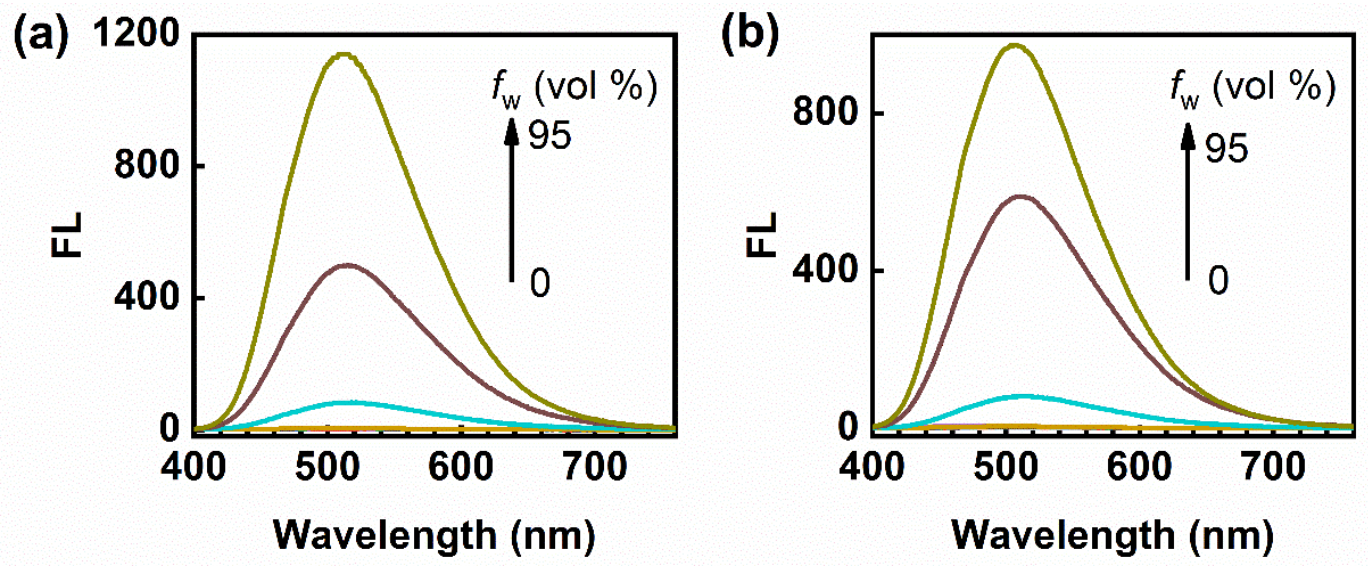

Figure S9. Emission spectra of DBVE (a) and DDBV (b) in THF/water mixtures. The excitation wavelength was $330 \mathrm{~nm}$. FL intensity increased with increased water content $f_{\mathrm{w}}$.
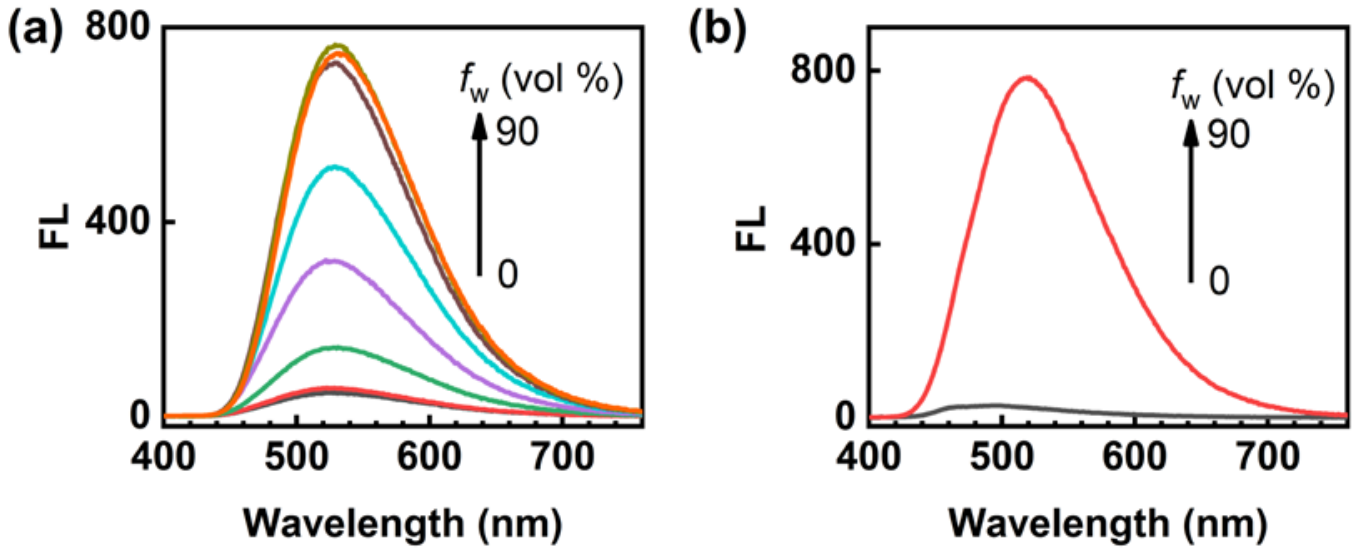

Figure S10. Emission spectra of PDBVE (a) and PDDBV (b) in THF/water mixtures. The excitation wavelength was $365 \mathrm{~nm}$. FL intensity increased with increased water content $f_{\mathrm{w}}$. 


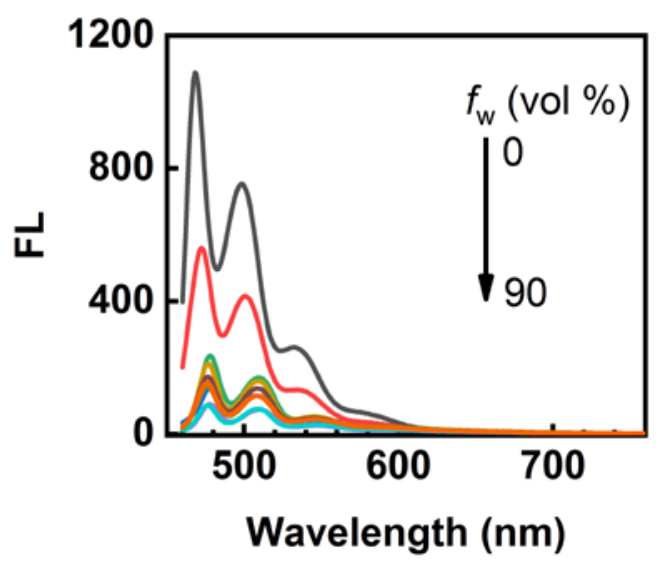

Figure S11. Emission spectra of PFlu recorded in THF/water mixtures. The excitation wavelength was $365 \mathrm{~nm}$. FL intensity decreased with increased water content $f_{\mathrm{w}}$.

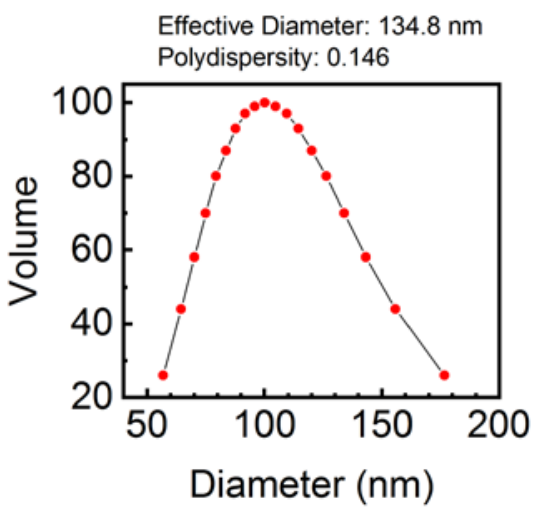

Figure S12. Particle size distribution of P(DBVE-co-Flu) in THF/water $\left(f_{\mathrm{w}}=90 \%\right)$ determined by dynamic light scattering experiment at $90^{\circ}$. The average diameter is $134 \mathrm{~nm}$ with a particle dispersion index (PDI) of 0.146, suggesting a polydisperse distribution of the particle size. (Note: The size distribution of a sample is reflected by PDI: PDI $<0.02$ for monodisperse sample, $0.02<\mathrm{PDI}<0.08$ for narrow disperse sample, and PDI $>0.08$ for polydisperse sample.) 
8. Fluorescence life times of polymers

Table S3. Fluorescence lifetimes $(\tau$, ns)of polyme rs

\begin{tabular}{|c|c|c|c|}
\hline \multirow{2}{*}{ Polymer } & \multicolumn{3}{|c|}{$\tau(\mathrm{ns})$} \\
\hline & Powder $^{a}$ & in $\mathrm{THF} / \mathrm{H}_{2} \mathrm{O}^{b}$ & in $\mathrm{THF}^{c}$ \\
\hline PDBVE & 1.184 & $-{ }^{d}$ & $-{ }^{d}$ \\
\hline P(DBVE-co-C10) & 1.299 & 1.676 & $-{ }^{d}$ \\
\hline P(DB VE-co-Flu) & 0.724 & 0.794 & 0.171 \\
\hline P(DBVE-co-Ben) & 1.062 & 1.305 & 0.294 \\
\hline PDDBV & 0.689 & $-{ }^{d}$ & $-{ }^{d}$ \\
\hline P(DDB V-co-C10) & 0.770 & 1.887 & $-{ }^{d}$ \\
\hline P(DDB V-co-Flu) & 0.362 & 0.325 & 0.162 \\
\hline P(DDB V-co-Ben) & 1.245 & 1.373 & 0.328 \\
\hline \multicolumn{4}{|c|}{$\begin{array}{l}{ }^{a} \text { Samples in powder form. }{ }^{b} \text { Samples prepared in } \mathrm{THF} / \mathrm{H}_{2} \mathrm{O} \text { mixtures }\left(f_{\mathrm{w}}=90 \%\right) \text { with polymer } \\
\text { concentration at } 10 \mu \mathrm{M} \text {. }{ }^{c} \text { Samples in THF solutions with polymer concentration at } 10 \mu \mathrm{M} .{ }^{d} \text { Insoluble } \\
\text { sample was not determined. }\end{array}$} \\
\hline
\end{tabular}

Table S4. Quantum yields and fluorescence life times of P(DBVE-co-Flu) with and without Pd ions

\begin{tabular}{ccc}
\hline Sample $^{a}$ & Quantum yield & Lifetime (ns) \\
\hline P(DB VE-co-Flu) & 0.374 & 0.794 \\
P(DBVE-co-Flu) with $\mathbf{1 0} \boldsymbol{\mu M} \mathbf{~ P d}^{2+}$ & 0.135 & 0.312 \\
${ }^{a}$ Polymer samples in THF/H $\mathbf{2} \mathbf{O}\left(f_{\mathbf{w}}=90 \%\right)$ at $10 \mu \mathrm{M}$. &
\end{tabular}


9. The limit of de tection for $\mathbf{P d}^{2+}$

(a)

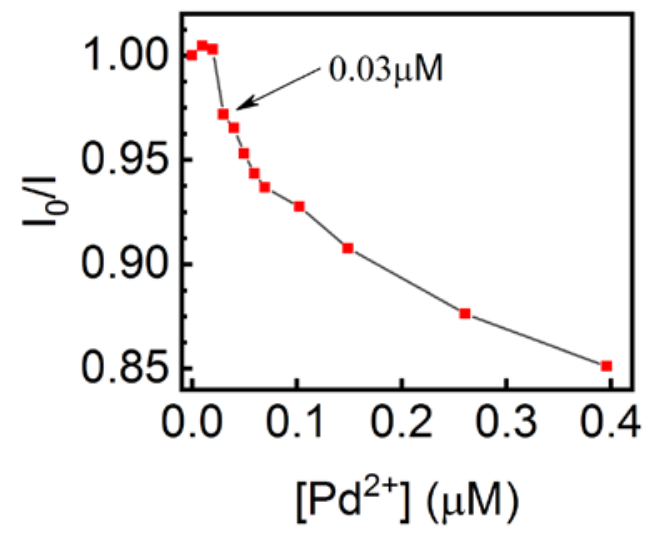

(b)

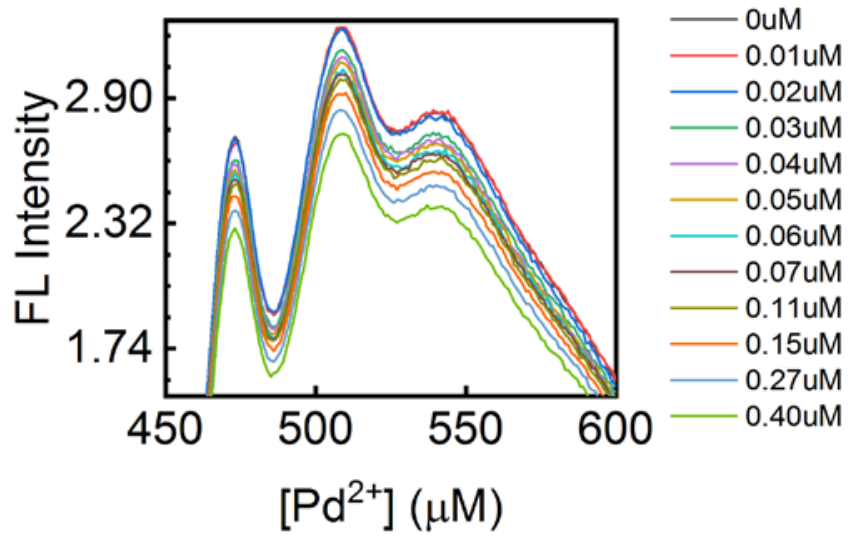

Figure S13. The limit of detection for $\mathrm{Pd}^{2+}$ of $\mathbf{P}(\mathbf{D B V E}-\mathbf{c o}-\mathbf{F l u})$ in THF/water mixtures at $f_{\mathrm{w}}=90 \%$. Upon the adding of trace amount of $\mathrm{Pd}^{2+}$, FL intensity at $508 \mathrm{~nm}$ was decreased. The lowest concentration of $\mathrm{Pd}^{2+}$ where a detectable variation of FL profiles occurs is $0.03 \mu \mathrm{M}$. This analys is follows the method reported in the literature ${ }^{2}$. 


\section{Modified Stern-Volmer tre atment of quenching data}

Modified Stern-Volmer treatments that account for heterogeneity of fluorophores provided more adequate fits to the observed quenching responses..$^{3-5}$ Assuming that the Stern-Volmer constant for the inaccessible fluorophores is zero and only a fraction of accessible fluorophores population $\left(f_{\mathrm{a}}\right)$ will interact with the quencher $(\mathrm{Q}), I_{0} /\left(I_{0}-I\right)$ is plotted Vs $1 /[\mathrm{Q}]$ to yield a linear plot, which is written as Eq. 2,

$$
\frac{I_{0}}{I_{0}-I}=\frac{1}{f_{\mathrm{a}} \mathrm{K}_{\mathrm{a}}[\mathrm{Q}]}+\frac{1}{f_{\mathrm{a}}}
$$

In this fitting, the $y$-intercept defines $f_{\mathrm{a}}^{-1}$ (where $f_{\mathrm{a}}$ is the fraction of accessible fluorophores), and the intercept/slope value provides $\mathrm{K}_{\mathrm{a}}$, the apparent Stern-Volmer constant for the accessible fluorophores.

As shown in Figure S14, Eq. 2 is applied for the treatment of quenching data of P(DBVE-co-Flu) by Pd ${ }^{2+}$ in THF/ $\mathrm{H}_{2} \mathrm{O}$ mixture $\left(f_{\mathrm{w}}=90 \%\right)$. The slope and intercept are $0.84 \mu \mathrm{M}^{-1}$ and 1.50 , respectively, giving $f_{\mathrm{a}}$ of 0.667 and $\mathrm{K}_{\mathrm{a}}$ of $1.8 \times 10^{6} \mathrm{M}^{-1}$. It is noted that the value of $\mathrm{K}_{\mathrm{a}}$ is too high for a quenching reaction based on molecular collision, ${ }^{3}$ which should be normally less than $100 \mathrm{M}^{-1}$. It is proposed that a photoinduced electron transfer occurs most probably.

However, we must be caution to interpret these data from the fitting. ${ }^{3}$ As can be seen from the equation, this analys is approach emphasizes differences in data at low [Q] range, which could be misleading if we consider the uncertainty of measurement at very low [Q]. Moreover, the sensor system in our work is rather complicated as the material exists as nano-aggregates. The population and local concentration of accessible fluorophores should be varied from the apparent [Q]. An accurate concentration is hard to predict. Therefore, we stress that the above fitting just gives an apparent value of $f_{\mathrm{a}}$ and $\mathrm{K}_{\mathrm{a}}$.
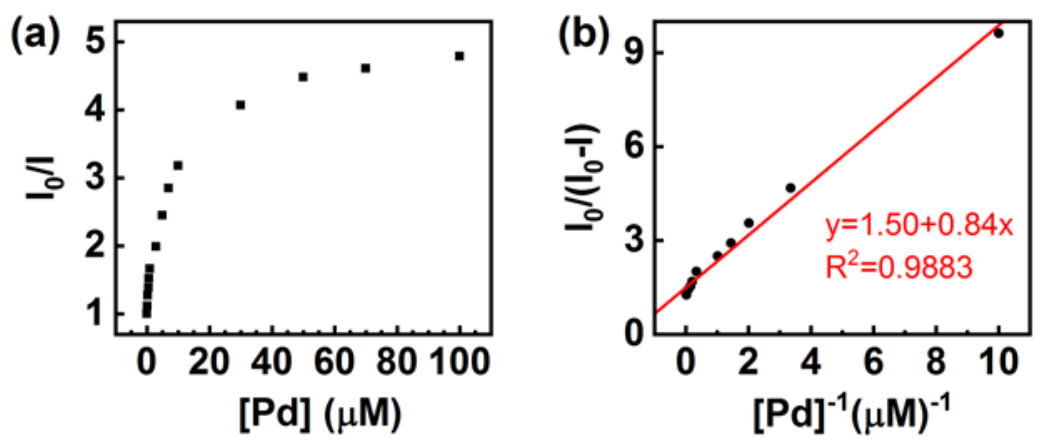

Figure S14. Stern-Volmer plot (a) and modified Stern-Volmer plot (b) of quenching data of P(DB VE-co-Flu) by $\mathrm{Pd}^{2+}$ in $\mathrm{THF} / \mathrm{H}_{2} \mathrm{O}$ mixture $\left(f_{\mathrm{w}}=90 \%\right)$. 
(a)

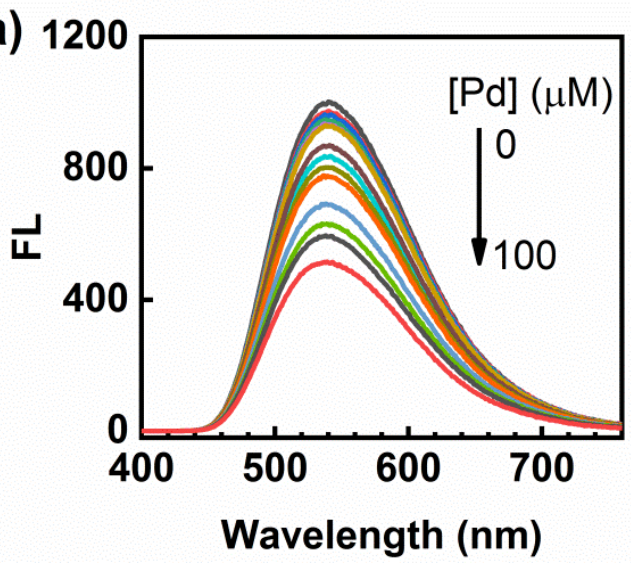

(c)

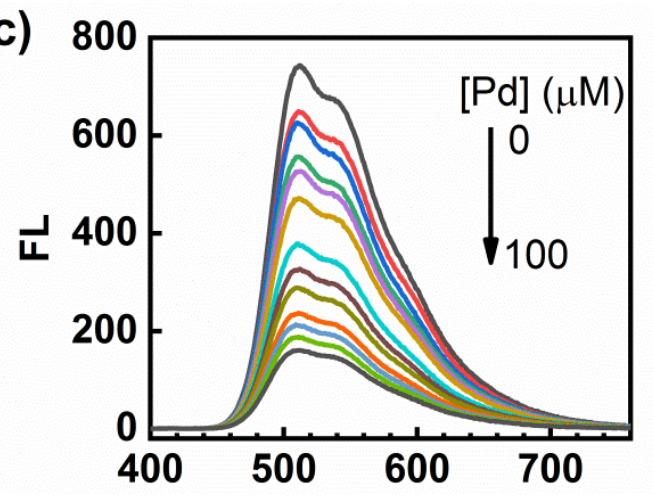

(b)

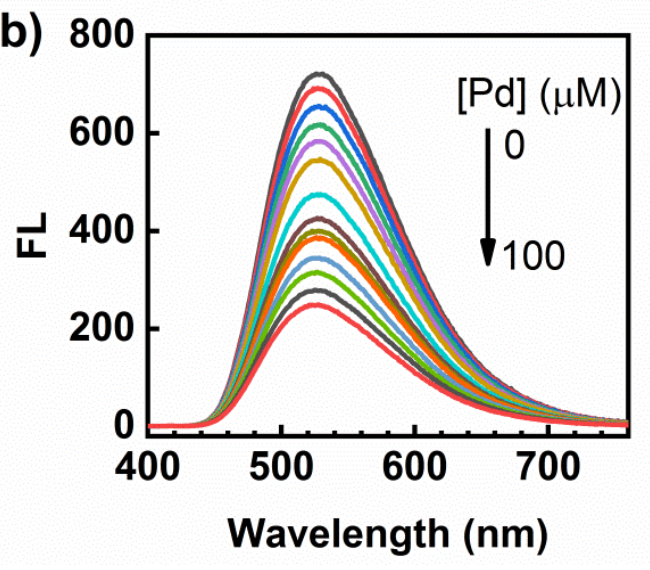

Figure S15. Emission spectra of PDBVE (a), P(DBVE-co-C10) (b), and P(DBVE-co-Ben) (c) in THF/ $\mathrm{H}_{2} \mathrm{O}$ mixture $\left(f_{\mathrm{w}}=90 \%\right)$ with the addition of $\mathrm{Pd}^{2+}(0 \sim 100 \mu \mathrm{M})$. 
(a)

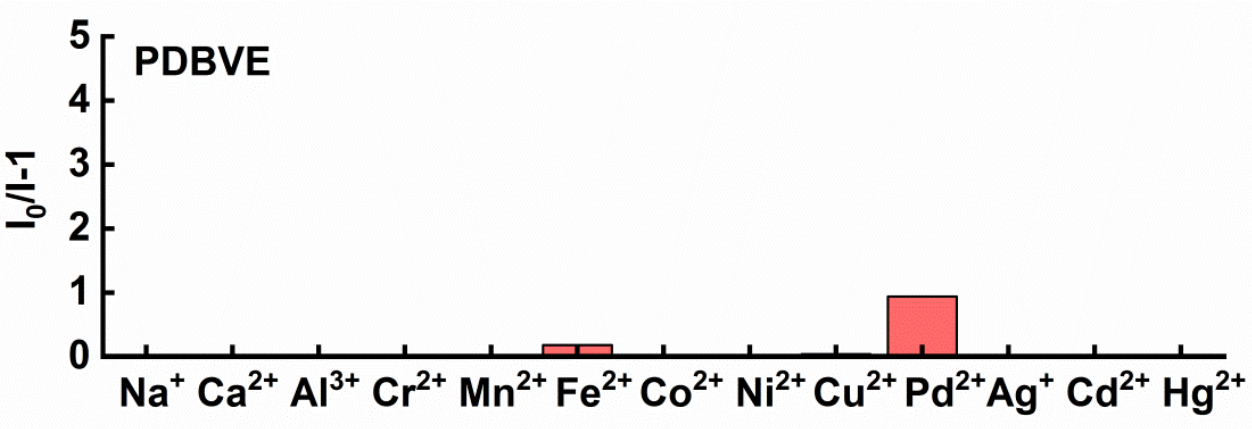

(b)

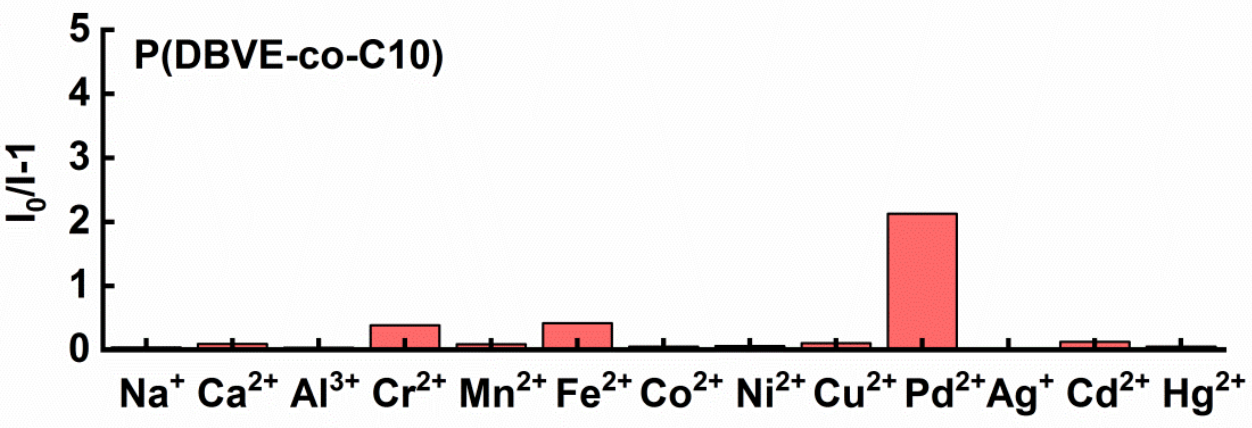

(c)

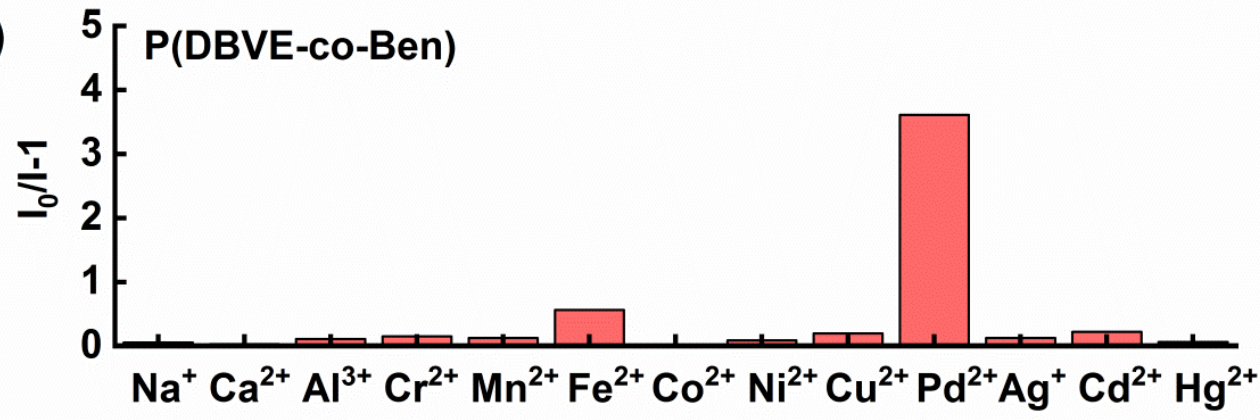

Figure S16. FL quench degrees of PDBVE (a), P(DBVE-co-C10) (b), and P(DBVE-co-Ben) (c) to $\mathrm{Pd}^{2+}$ and other metal ions at $\mathrm{c}_{\text {(ion) }}=100 \mu \mathrm{M}$. 

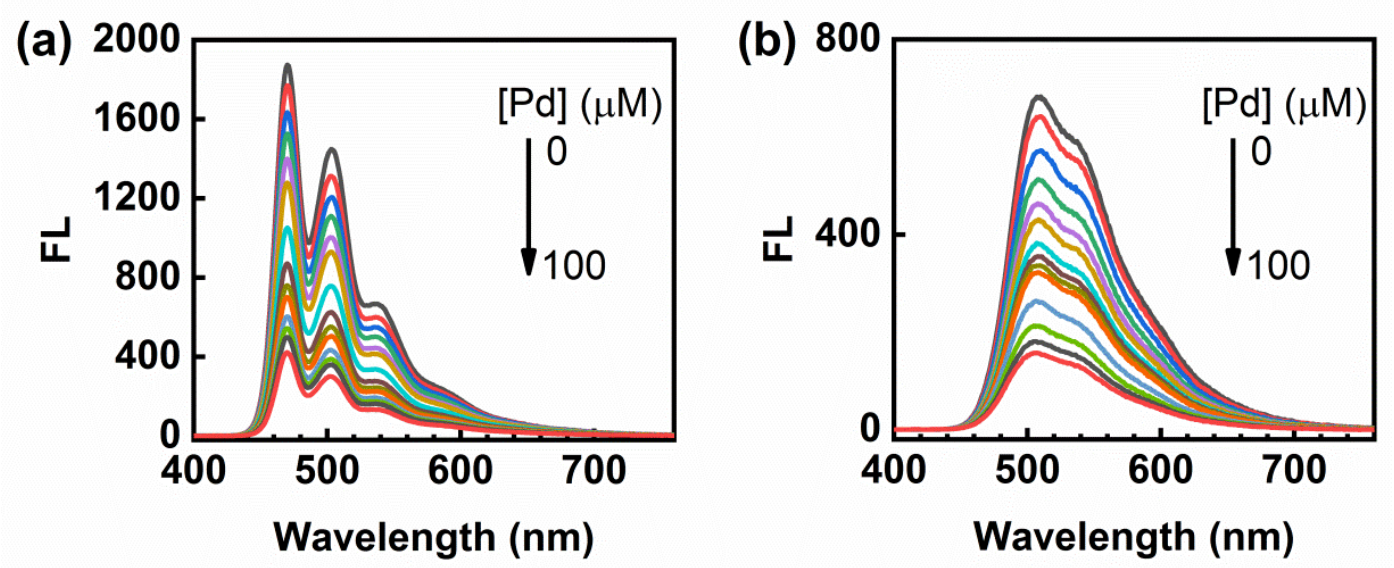

Figure S17. Emission spectra of $\mathbf{P}\left(\mathbf{D D B}\right.$ V-co-Flu) (a) and $\mathbf{P}\left(\mathbf{D D B}\right.$ V-co-Ben) (b) in THF/ $\mathrm{H}_{2} \mathrm{O}$ mixture $\left(f_{\mathrm{w}}\right.$ $=90 \%)$ with the addition of $\mathrm{Pd}^{2+}(0 \sim 100 \mu \mathrm{M})$.

(a)

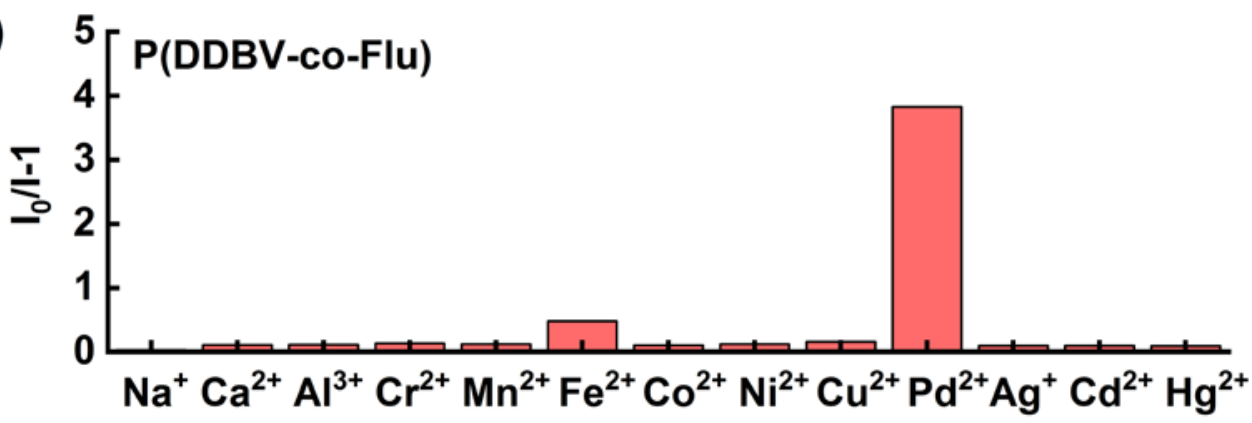

(b)

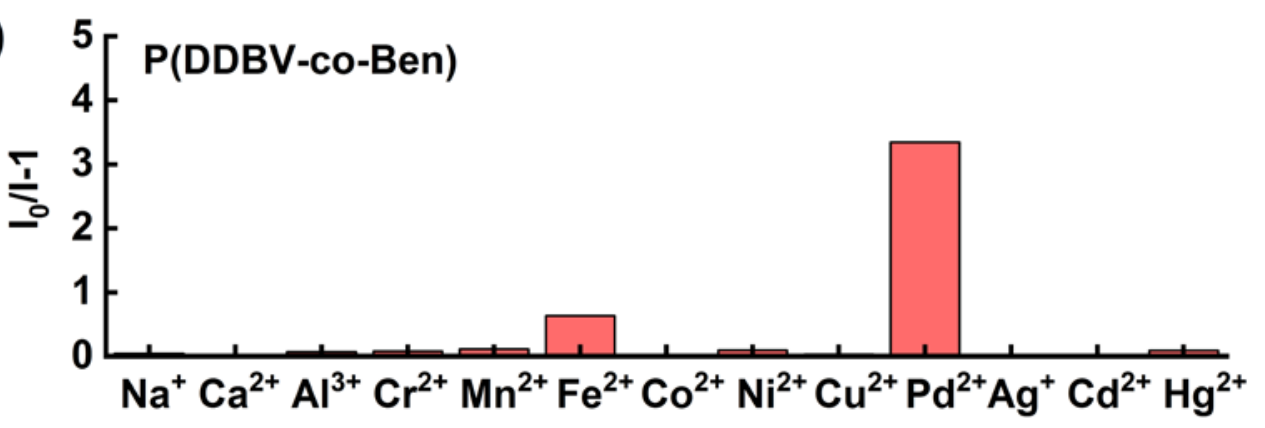

Figure S18. FL quench degrees of $\mathbf{P}\left(\mathbf{D D B V}\right.$-co-Flu) (a) and $\mathbf{P}\left(\mathbf{D D B V}\right.$-co-Ben) (b) to $\mathrm{Pd}^{2+}$ and other metal ions at $\mathrm{c}_{(\mathrm{ion})}=100 \mu \mathrm{M}$. 

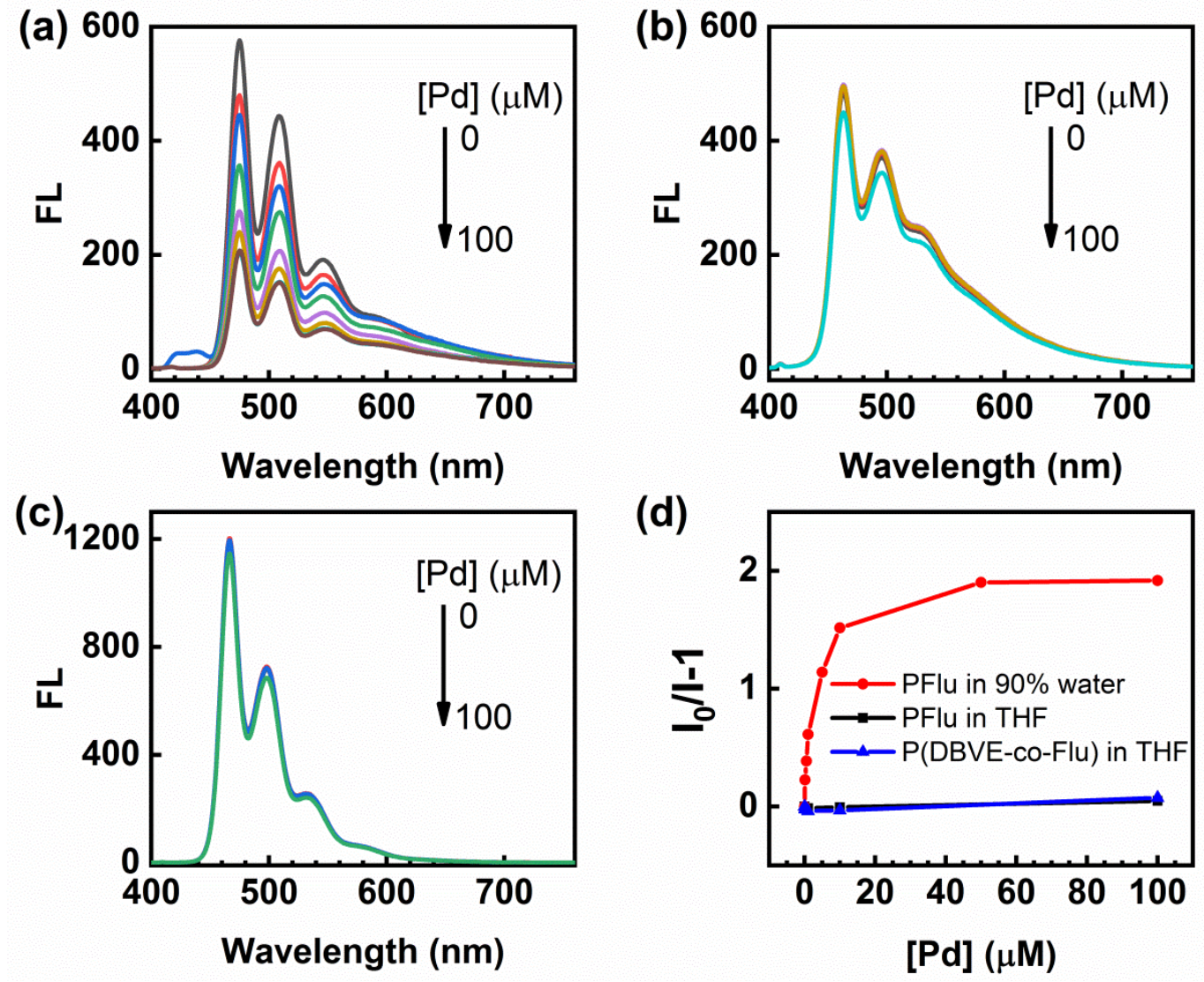

Figure S19. Solvent effect on FL responses of polymers with the addition of $\operatorname{Pd}^{2+}(0 \sim 100 \mu \mathrm{M})$. (a) PFlu in THF/ $\mathrm{H}_{2} \mathrm{O}$ mixture $\left(f_{\mathrm{w}}=90 \%\right)$; (b) P(DBVE-co-Flu) in THF solution; (c) PFlu in THF solution; (d) Plots of quench degree of polymers versus [Pd] in different solvent systems. There were no FL responses when the detection experiments were performed in THF solution. 


\section{Comparison of the de tection for $\mathbf{P d}^{2+}$ by conjugated polymers}

Table S5. Comparison of the de tection of $\mathrm{Pd}^{2+}$ by conjugated polymers

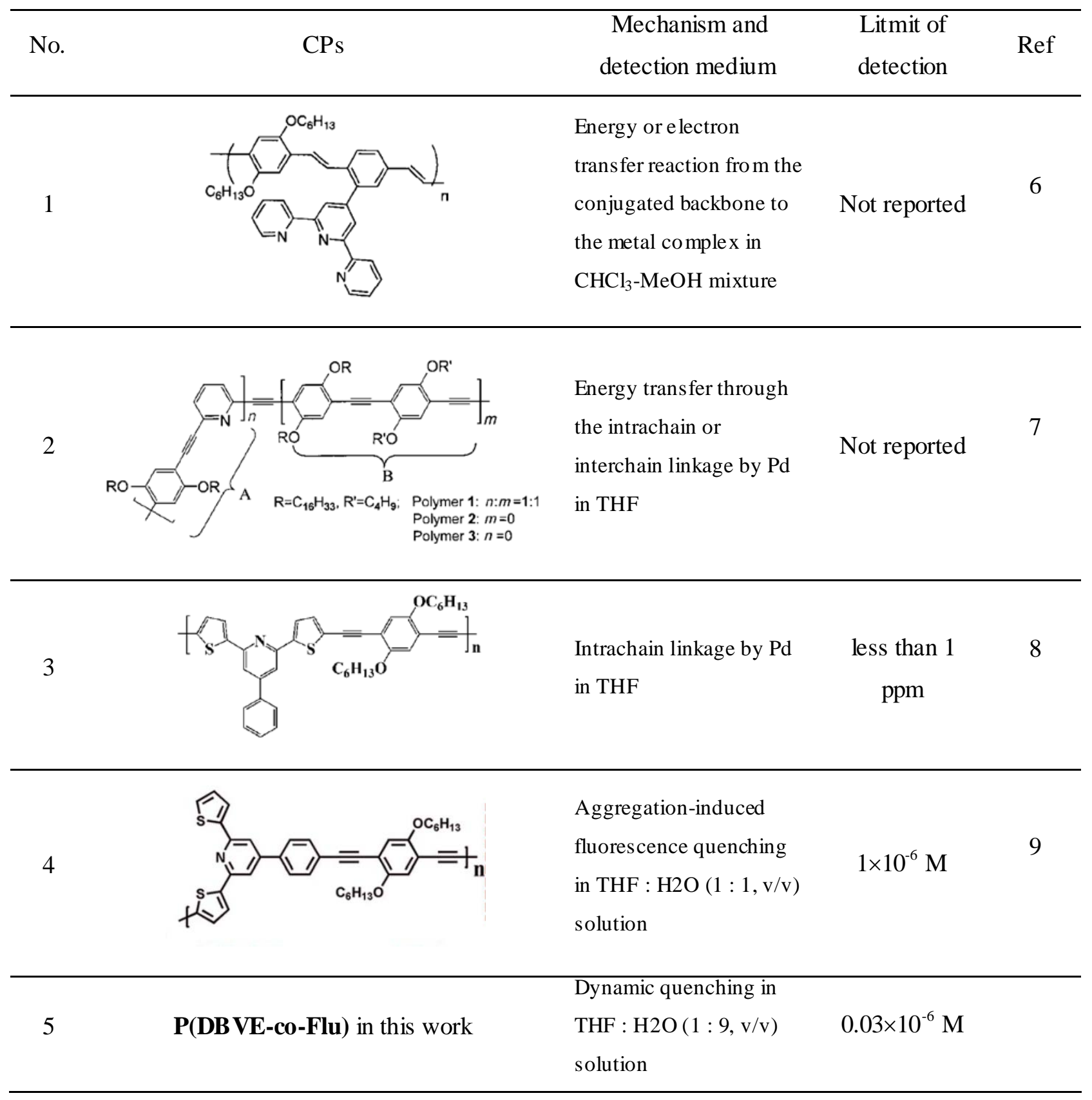




\section{References}

(1) Nomura, K.; Miyamoto, Y.; Morimoto, H.; Geerts, Y., Acyclic diene metathesis polymerization of 2,5-dialkyl-1,4-divinylbenzene with molybdenum or ruthenium catalysts: Factors affecting the precise synthesis of defect-free, high-molecular-weight trans-poly(p-phenylene vinylene)s. J. Polym. Sci., Part A: Polym. Chem. 2005, 43, 6166-6177.

(2) Sanda, S.; Parshamoni, S.; Biswas, S.; Konar, S., Highly selective detection of palladium and picric acid by a luminescent MOF: a dual functional fluorescent sensor. Chem. Commun. 2015, 51, 6576-6579.

(3) Eftink, M. R., Fluorescence Quenching Reactions. In Biophysical and Biochemical Aspects of Fluorescence Spectroscopy, Dewey, T. G., Ed. Springer US: Boston, MA, 1991; pp 1-41.

(4) Tovar, J. D.; Claussen, R. C.; Stupp, S. I., Probing the Interior of Peptide Amphiphile Supramolecular Aggregates. J. Am. Chem. Soc. 2005, 127, 7337-7345.

(5) Lehrer, S., Solute perturbation of protein fluorescence. Quenching of the tryptophyl fluorescence of model compounds and of lysozyme by iodide ion. Biochemistry 1971, 10, 3254-3263.

(6) Kimura, M.; Horai, T.; Hanabusa, K.; Shirai, H., Fluorescence Chemosensor for Metal Ions Using Conjugated Polymers. Adv. Mater. 1998, 10, 459-462.

(7) Huang, H.; Wang, K.; Tan, W.; An, D.; Yang, X.; Huang, S.; Zhai, Q.; Zhou, L.; Jin, Y., Design of a Modular-Based Fluorescent Conjugated Polymer for Selective Sensing. Angew. Chem. Int. Ed. 2004, 43, 5635-5638.

(8) Liu, B.; Bao, Y.; Du, F.; Wang, H.; Tian, J.; Bai, R., Synthesis and characterization of a fluorescent polymer containing 2,6-bis(2-thienyl)pyridine moieties as a highly effic ient sensor for $\mathrm{Pd}^{2+}$ detection. Chem. Commun. 2011, 47, 1731-1733.

(9) Liu, B.; Bao, Y.; Wang, H.; Du, F.; Tian, J.; Li, Q.; Wang, T.; Bai, R., An efficient conjugated polymer sensor based on the aggregation-induced fluorescence quenching mechanism for the specific detection of palladium and platinum ions. J. Mater. Chem. 2012, 22, 3555-3561. 
14. ${ }^{1} \mathrm{H}$ NMR and ${ }^{13} \mathrm{C}$ NMR spectra of compounds (Inserted are magnified plots)

\section{Compound 2- ${ }^{1} \mathbf{H}$ NMR}

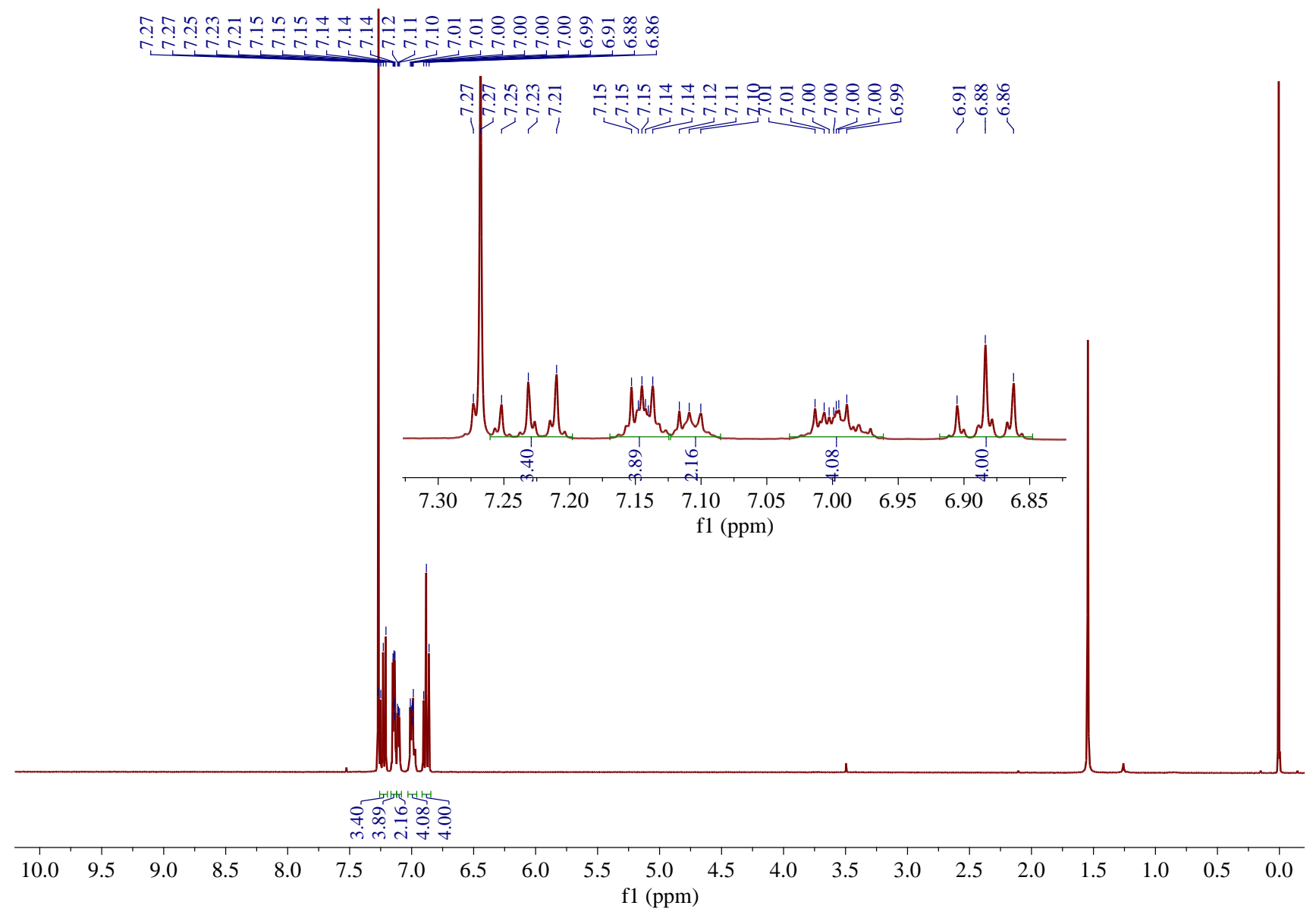




\section{Compound $2-{ }^{13} \mathrm{C}$ NMR}

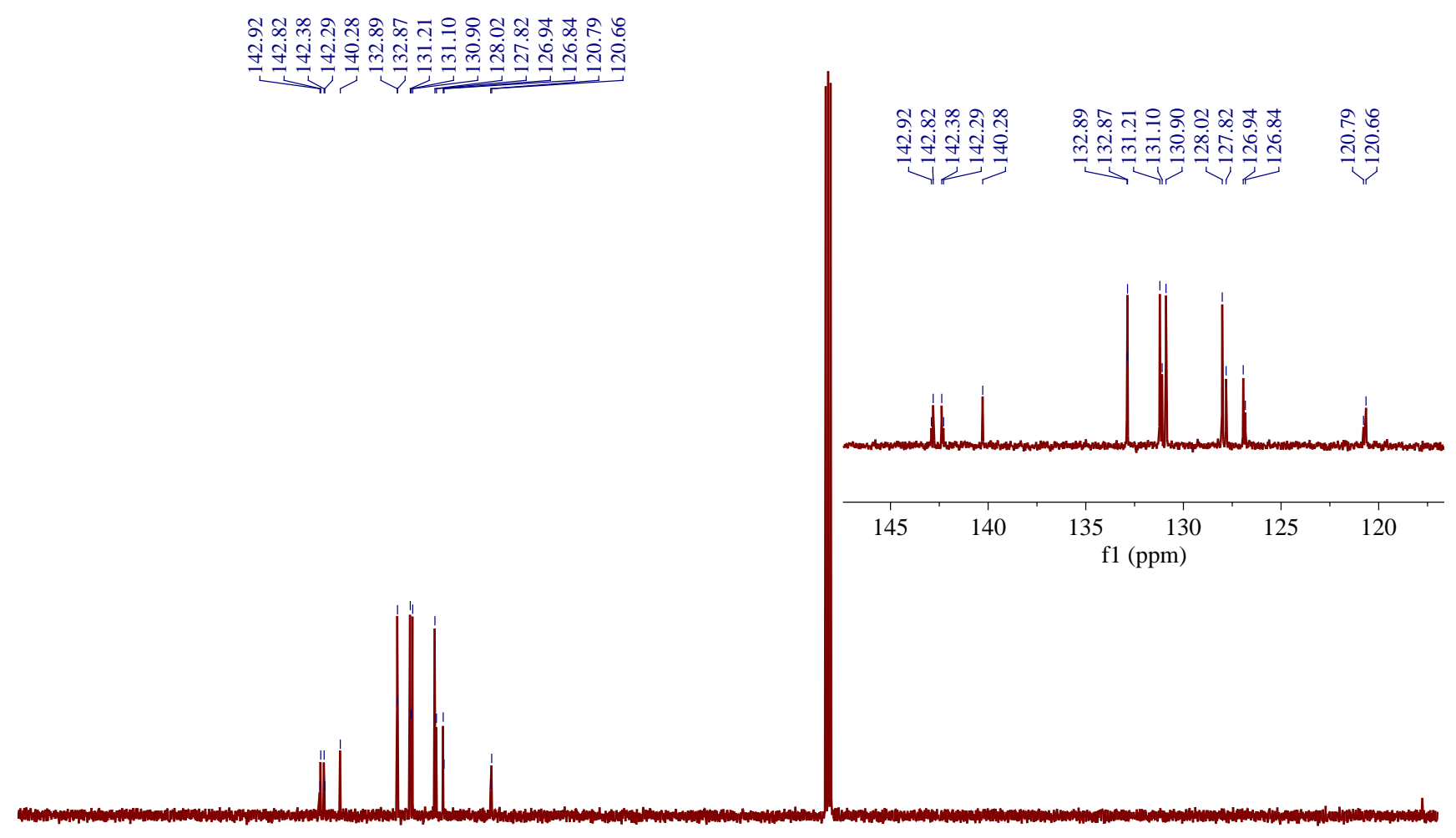

\begin{tabular}{|c|c|c|c|c|c|c|c|c|c|c|c|c|c|c|c|c|c|c|}
\hline 180 & 170 & 160 & 150 & 140 & 130 & 120 & 110 & 100 & $\begin{array}{c}90 \\
1(\mathrm{ppm})\end{array}$ & 80 & 70 & 60 & 50 & 40 & 30 & 20 & 10 & 0 \\
\hline
\end{tabular}




\section{DBVE- ${ }^{1} \mathrm{H}$ NMR}

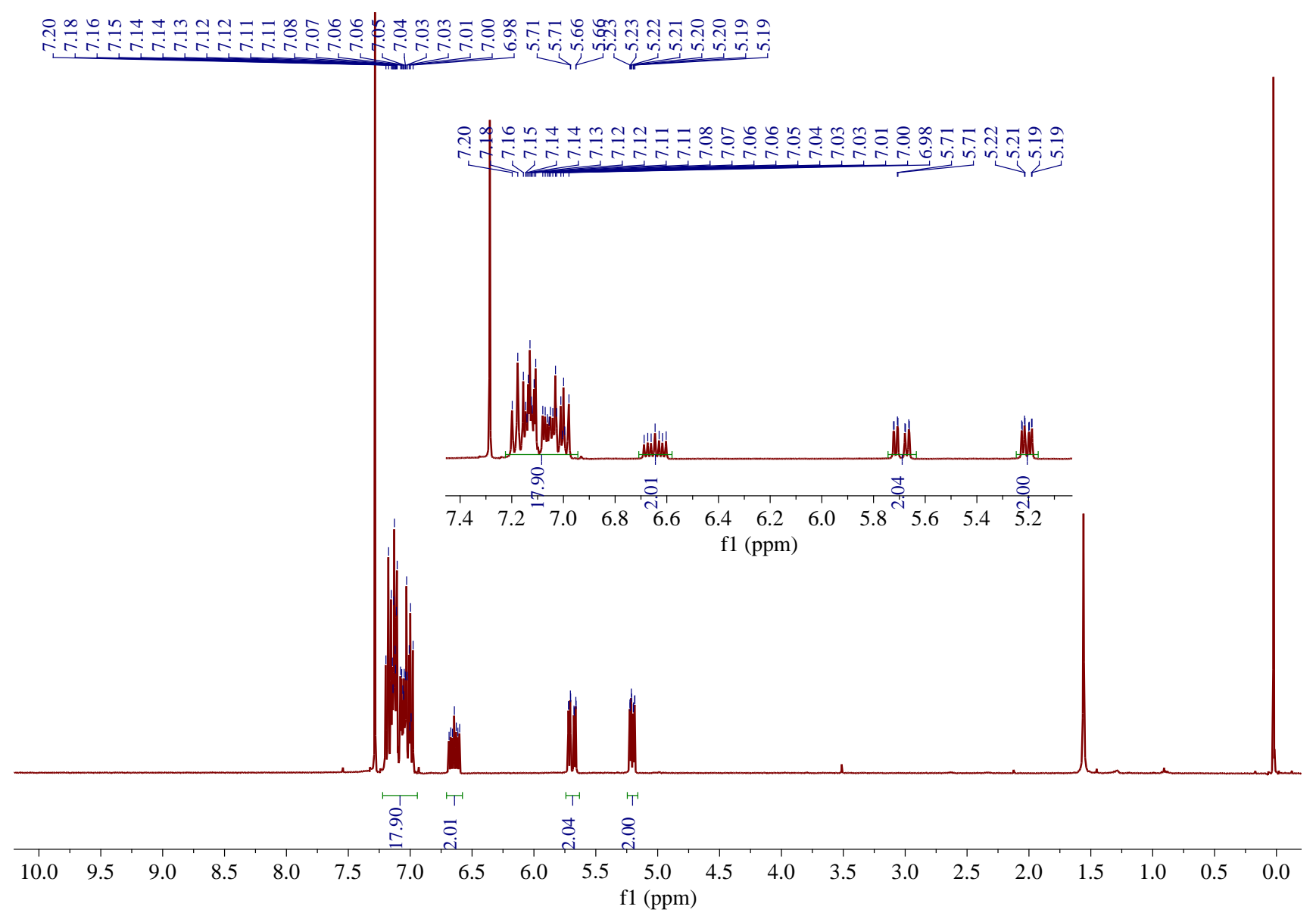


DBVE- ${ }^{13}$ C NMR

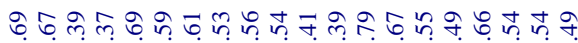

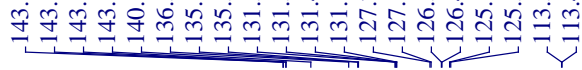

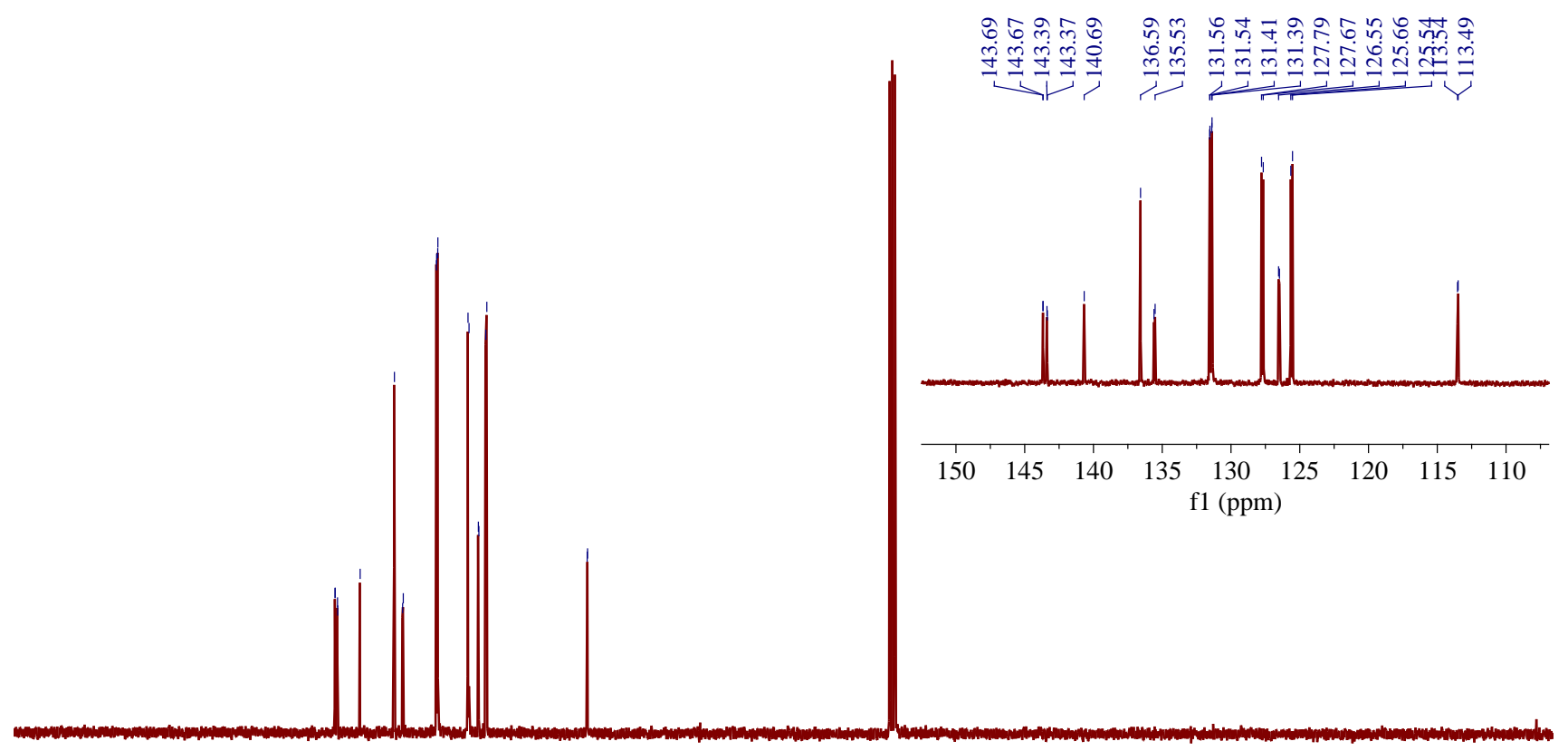

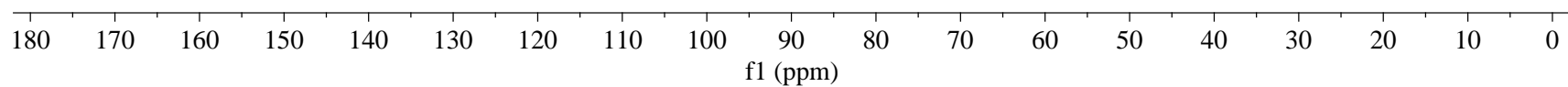




\section{Compound 4- ${ }^{1} \mathrm{H}$ NMR}

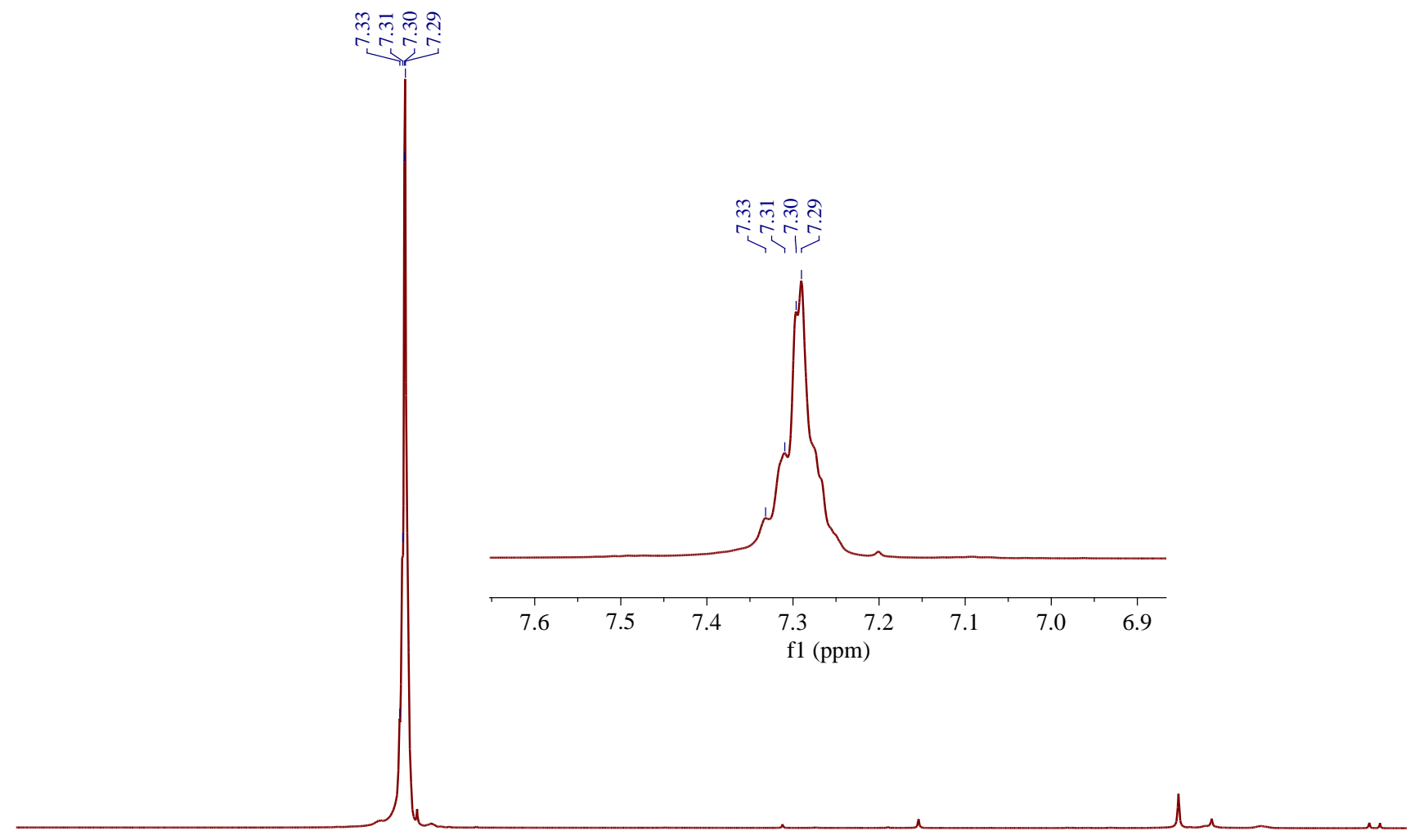

$\begin{array}{lllllllllllllllllllll}10.0 & 9.5 & 9.0 & 8.5 & 8.0 & 7.5 & 7.0 & 6.5 & 6.0 & 5.5 & \begin{array}{c}5.0 \\ \mathrm{f} 1(\mathrm{ppm})\end{array} & 4.5 & 4.0 & 3.5 & 3.0 & 2.5 & 2.0 & 1.5 & 1.0 & 0.5 & 0.0\end{array}$




\section{Compound 4- ${ }^{13} \mathrm{C}$ NMR}

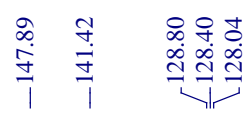

ڤิ่
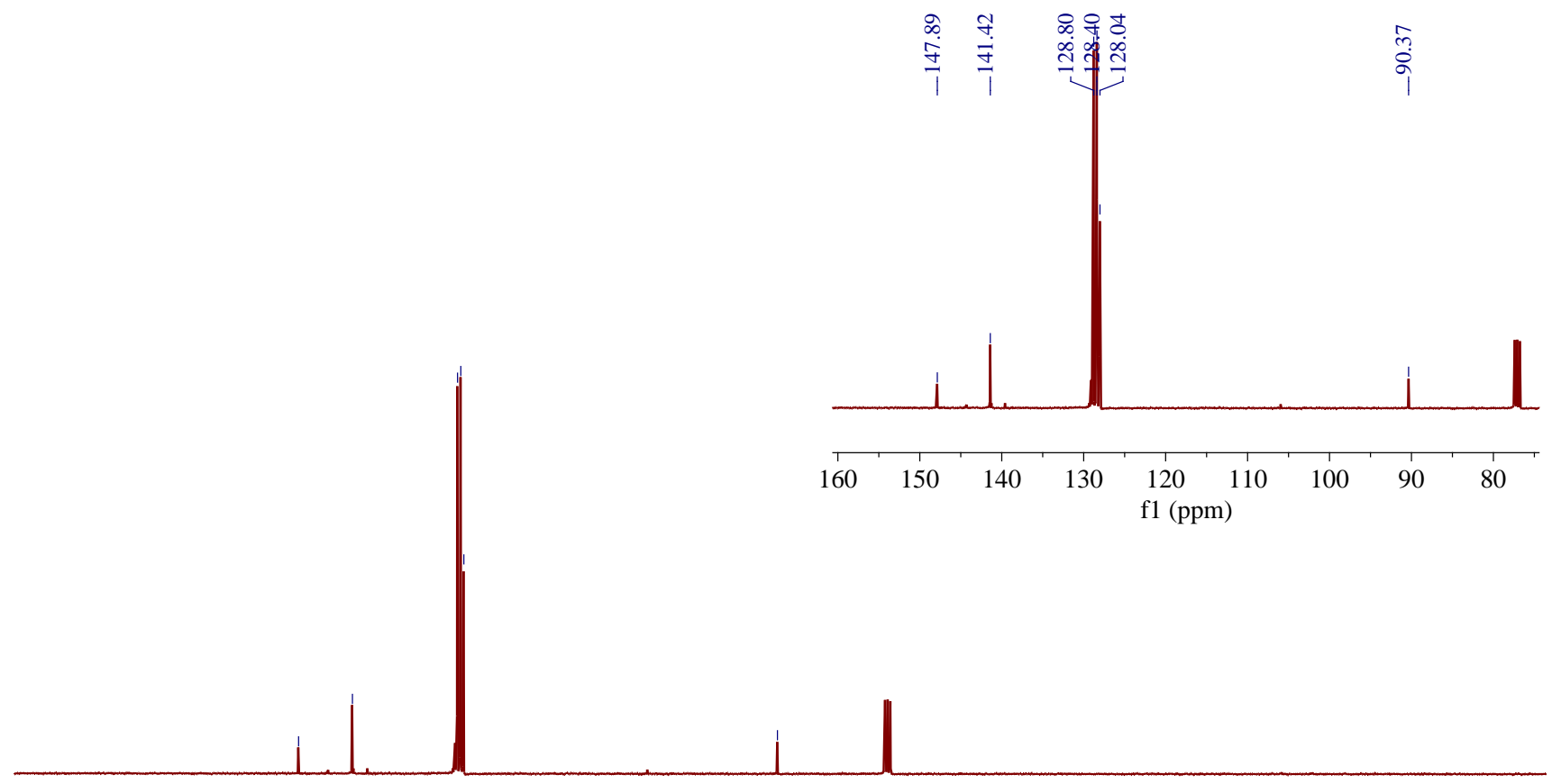

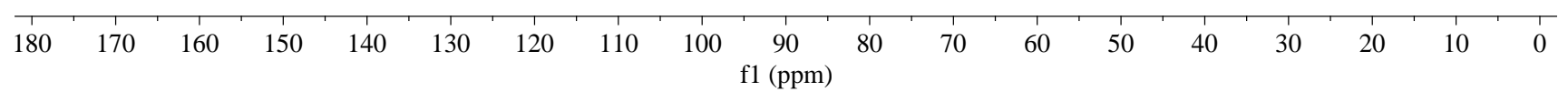




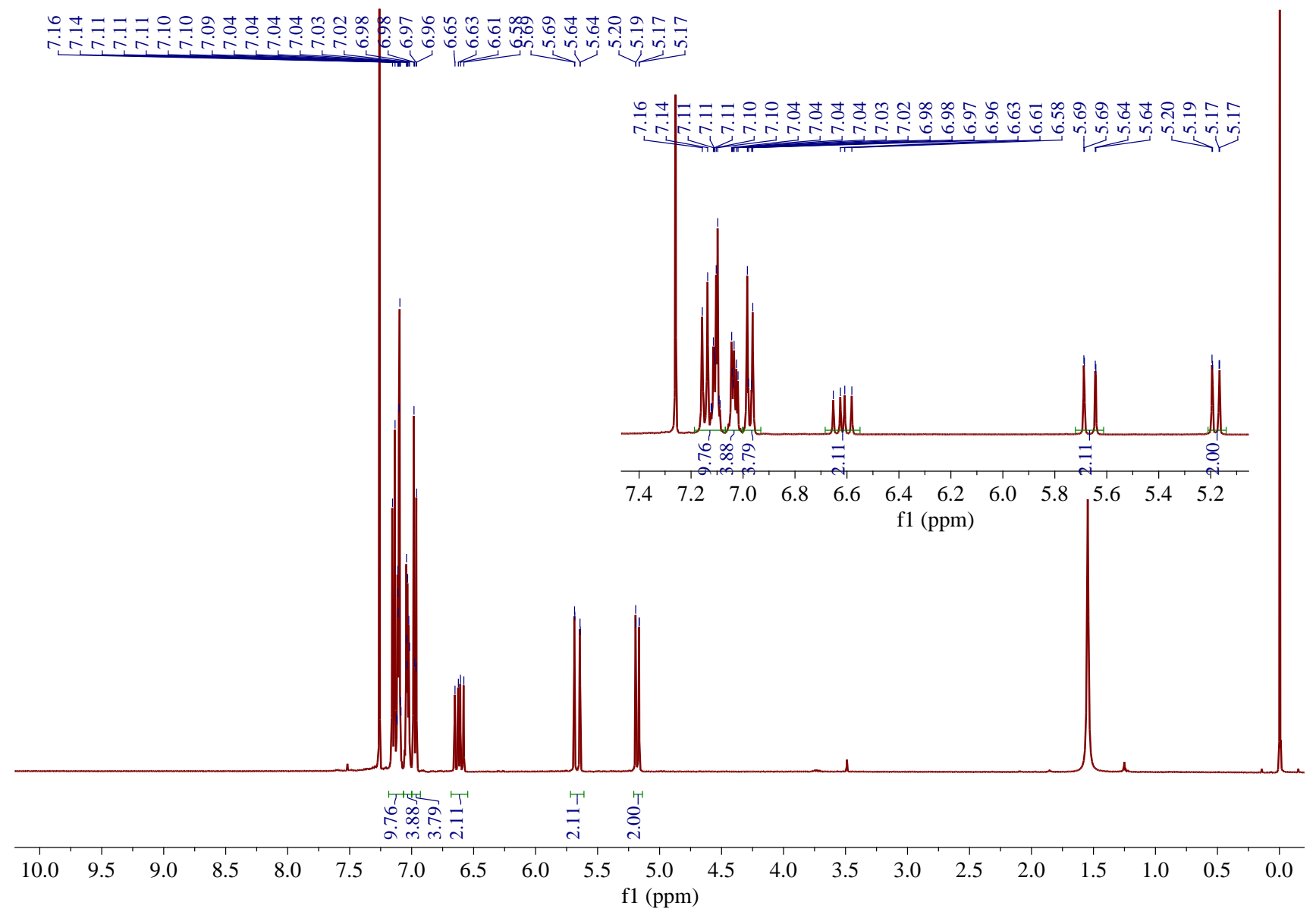


DDB V- ${ }^{13} \mathrm{C}$ NMR

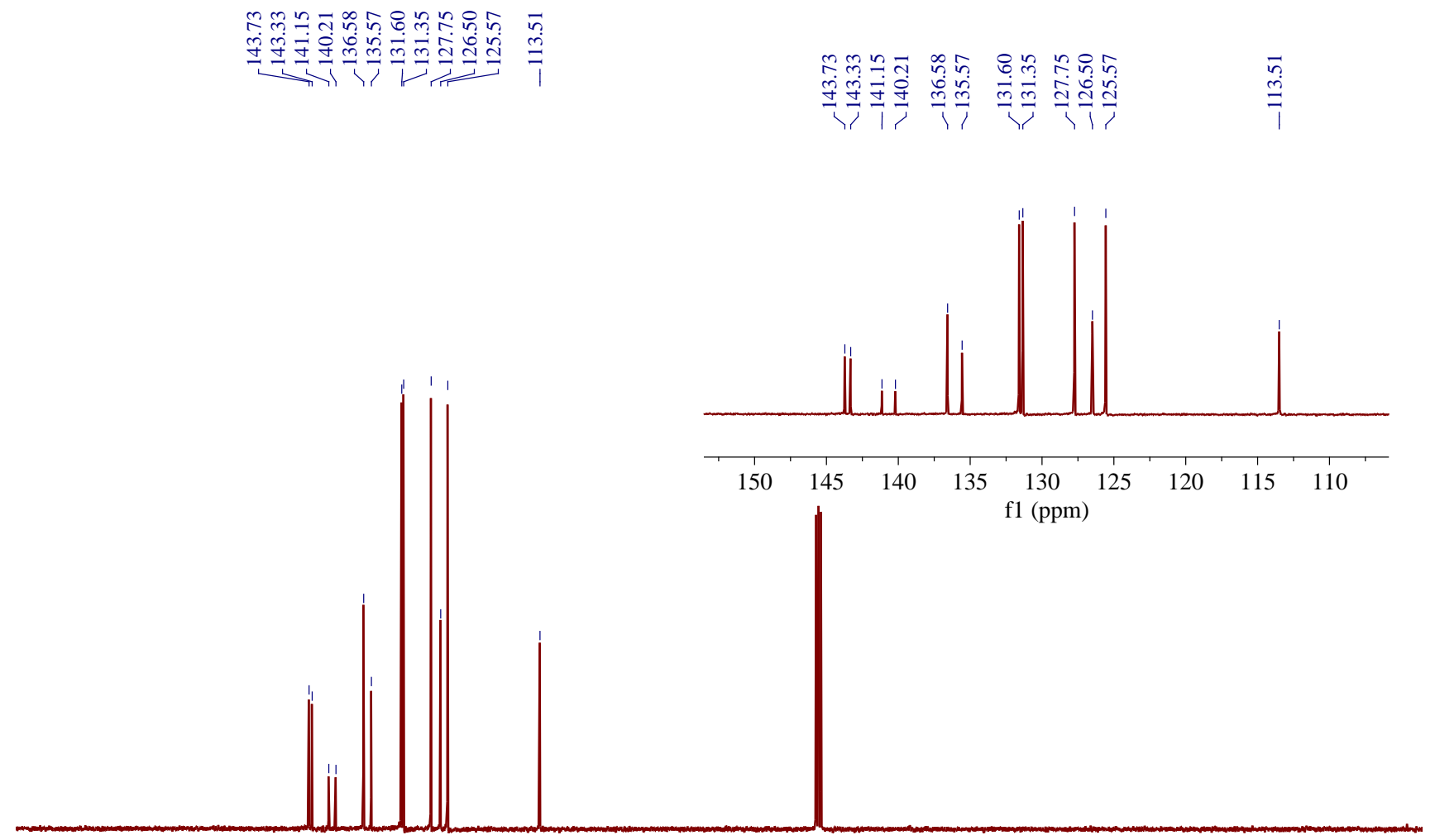

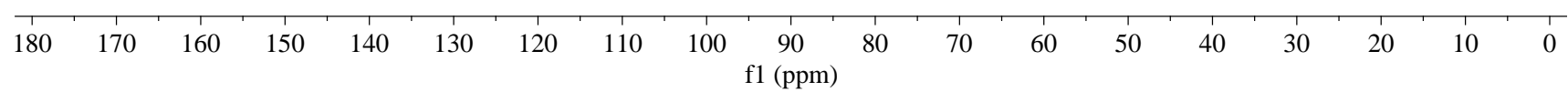


Flu $-{ }^{1} \mathrm{H}$ NMR

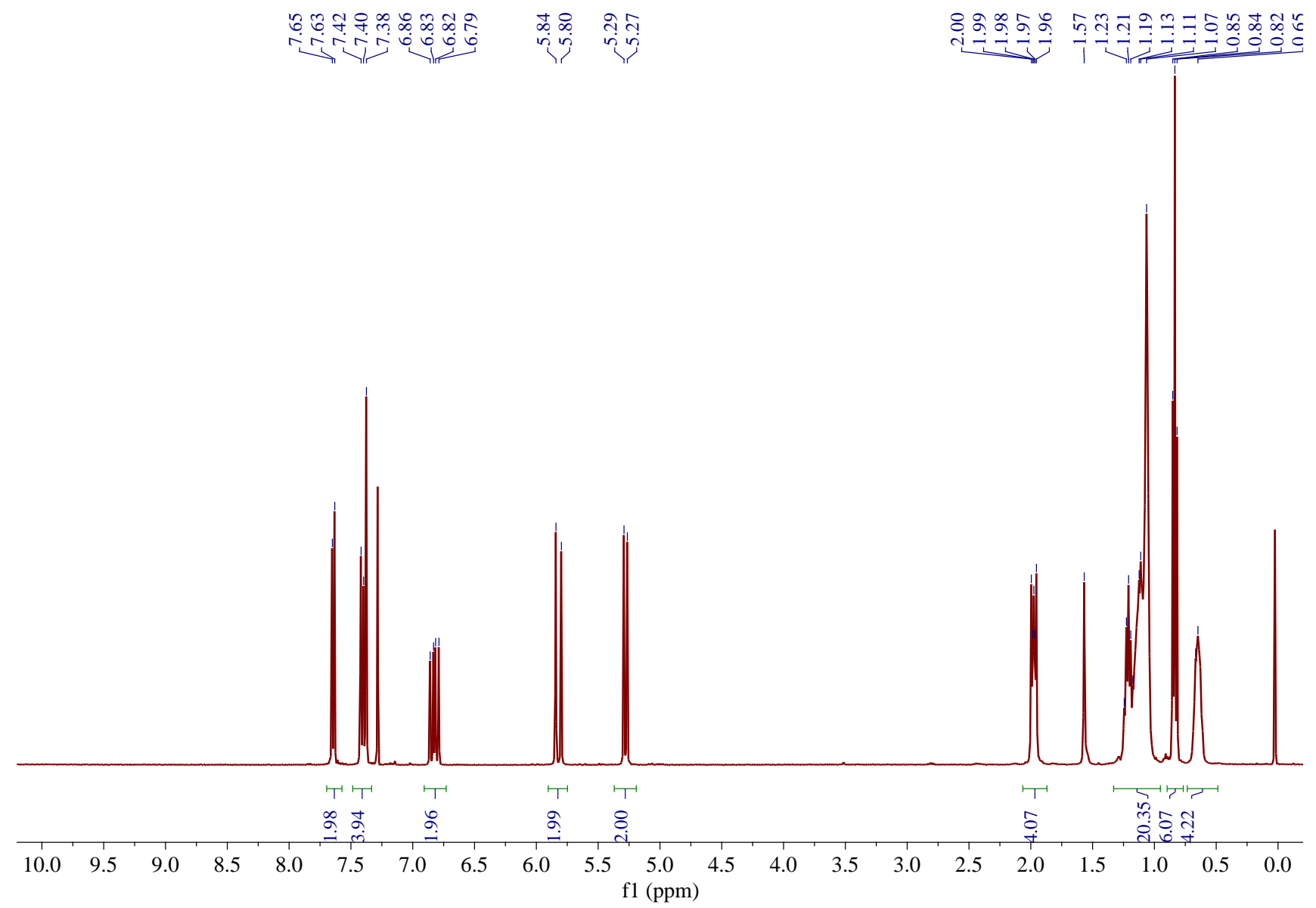


Flu- ${ }^{13}$ C NMR

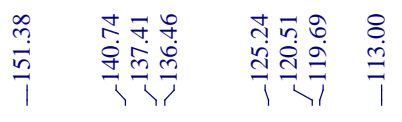

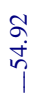

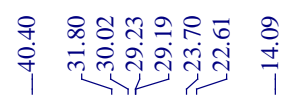
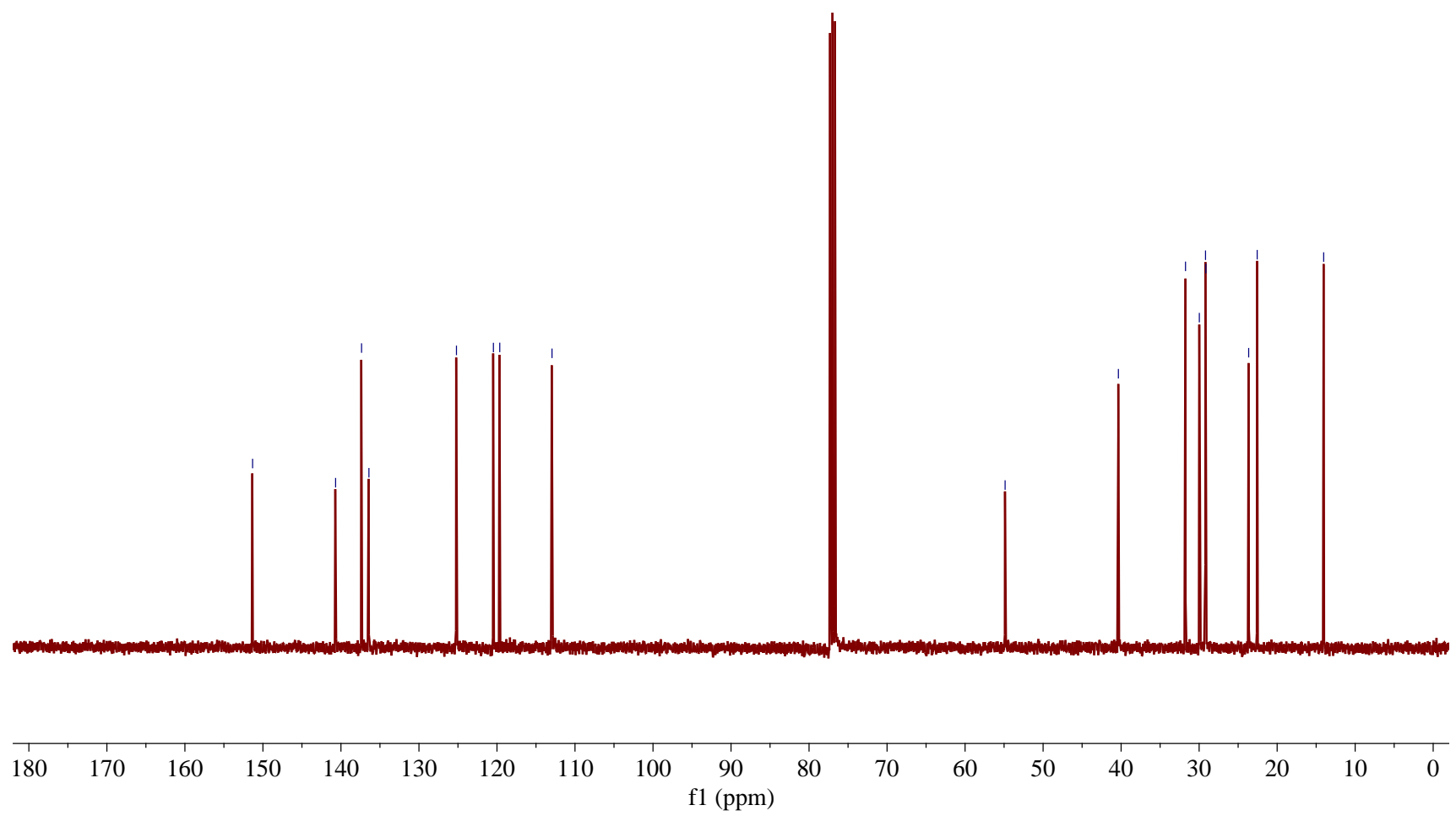

37 


\section{Ben ${ }^{-1}$ H NMR}

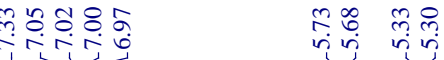

i这实

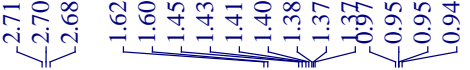

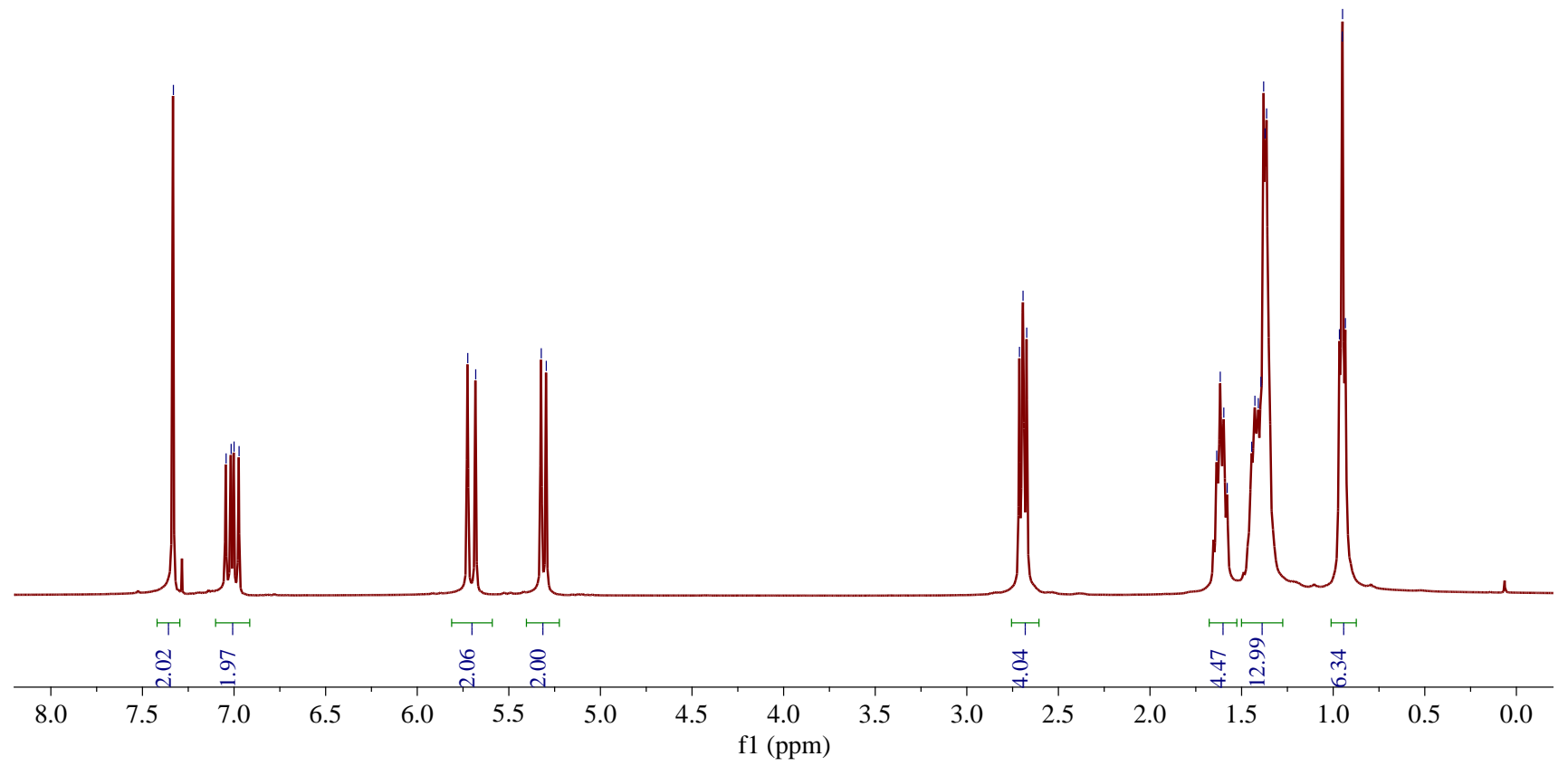


Ben- ${ }^{13}$ C NMR
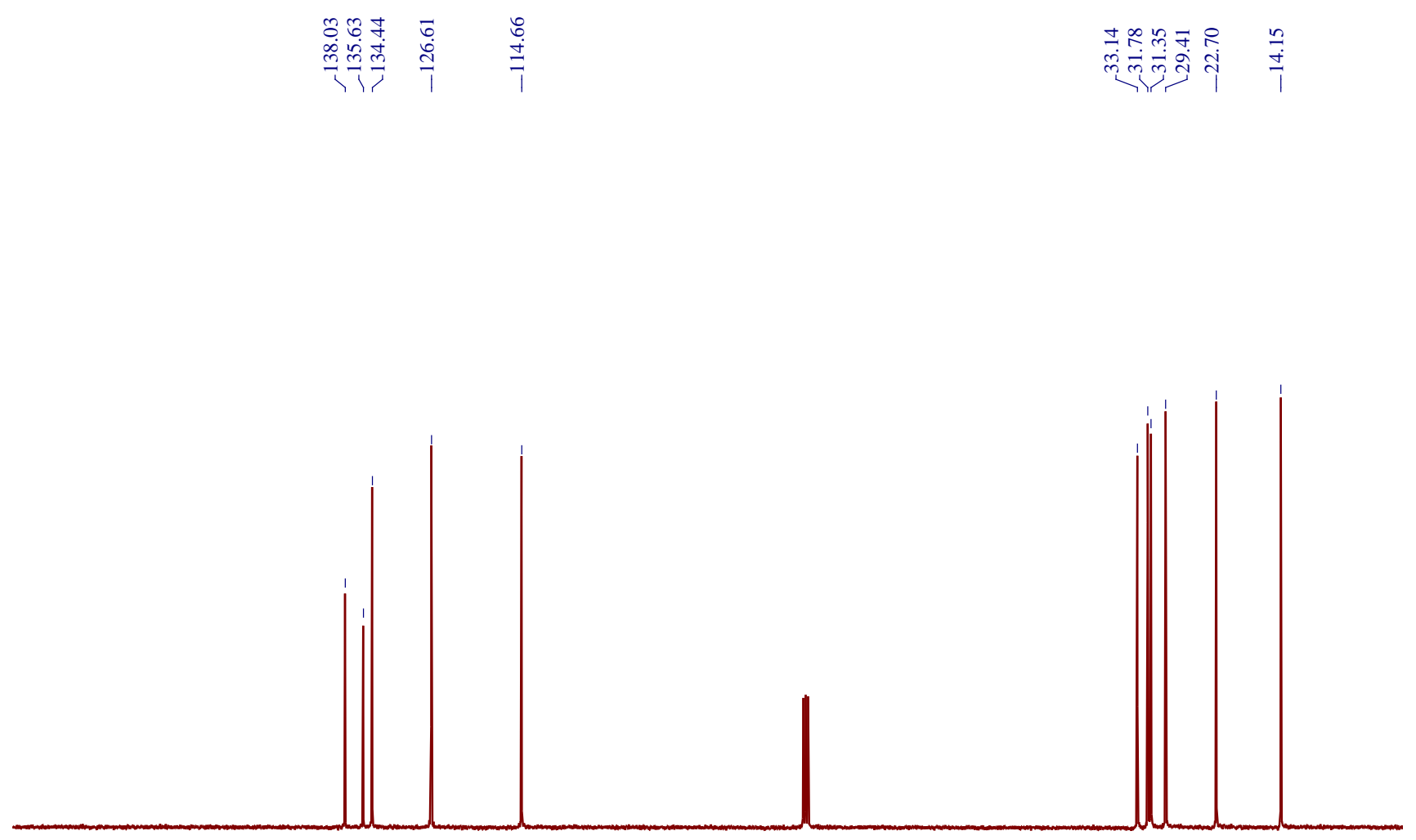

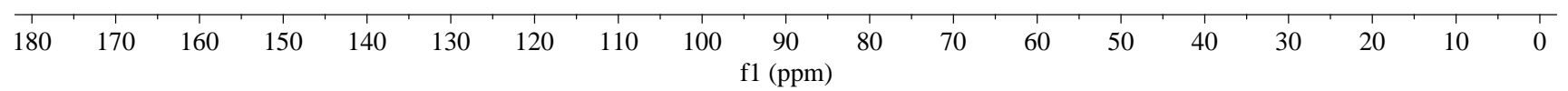




\section{PDB VE}

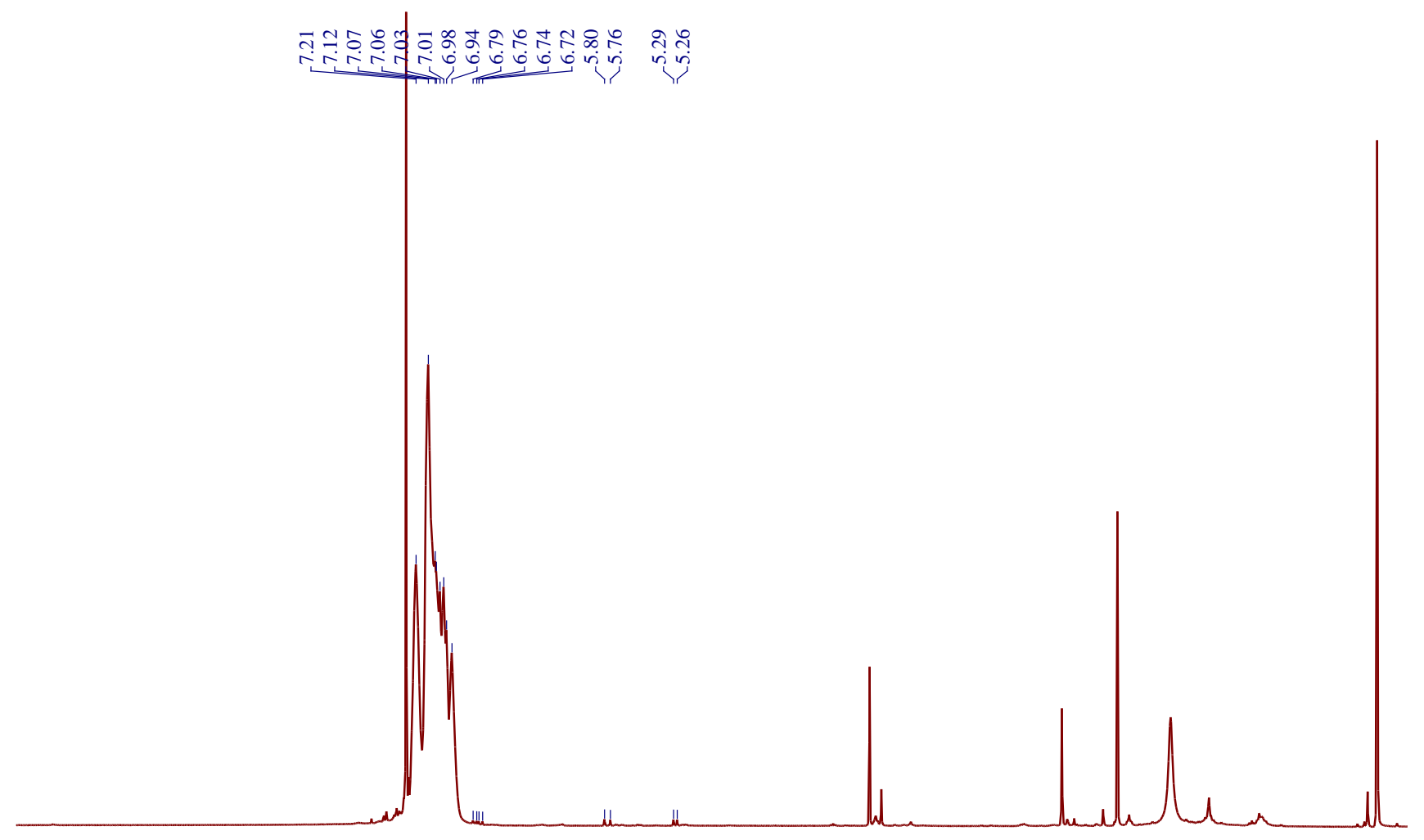

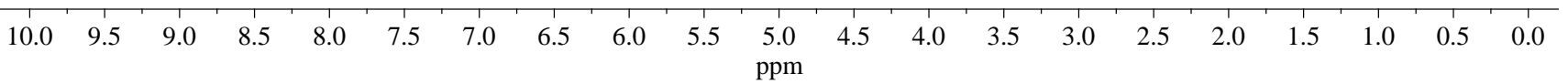




\section{PC10}

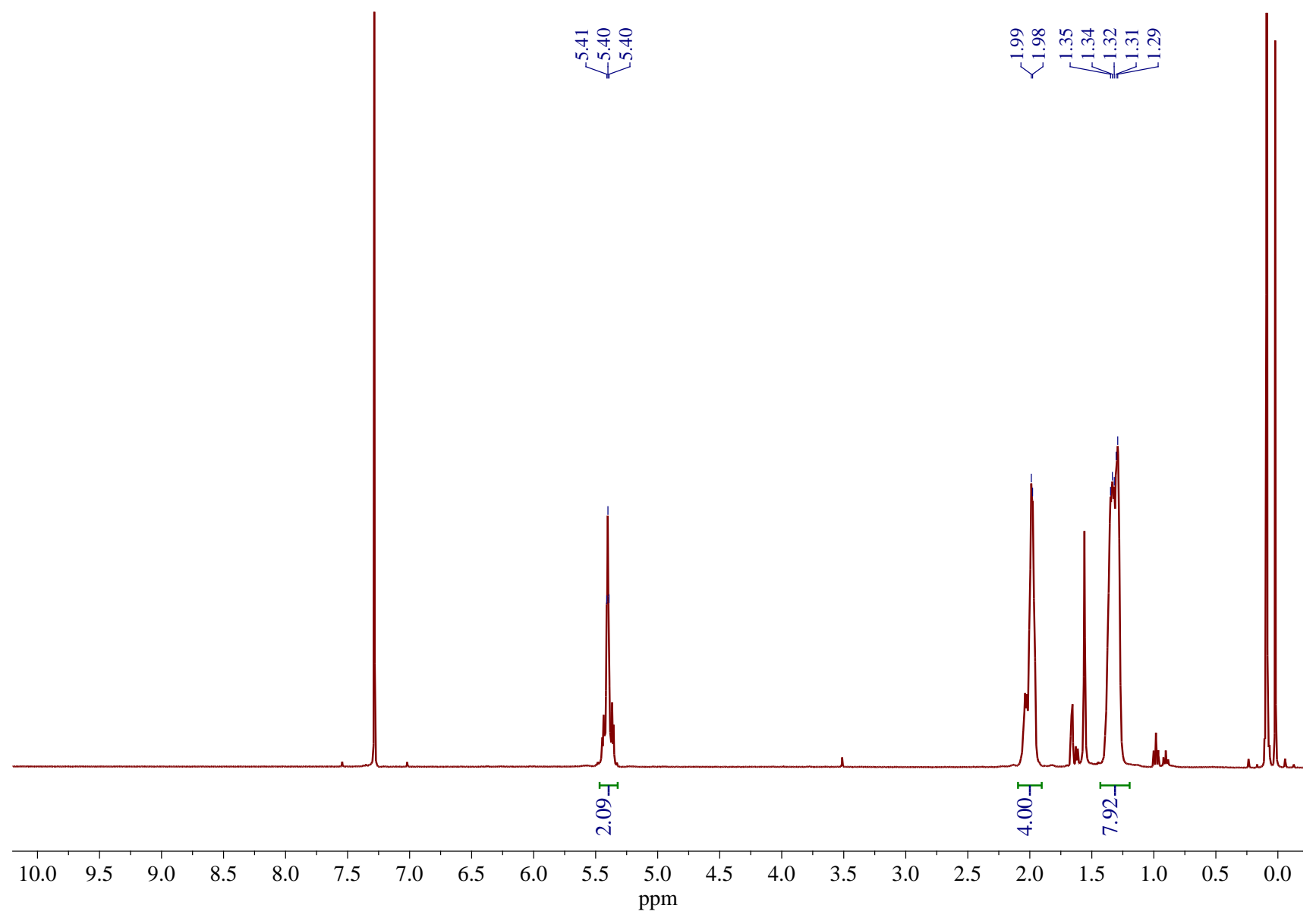




\section{PFlu}

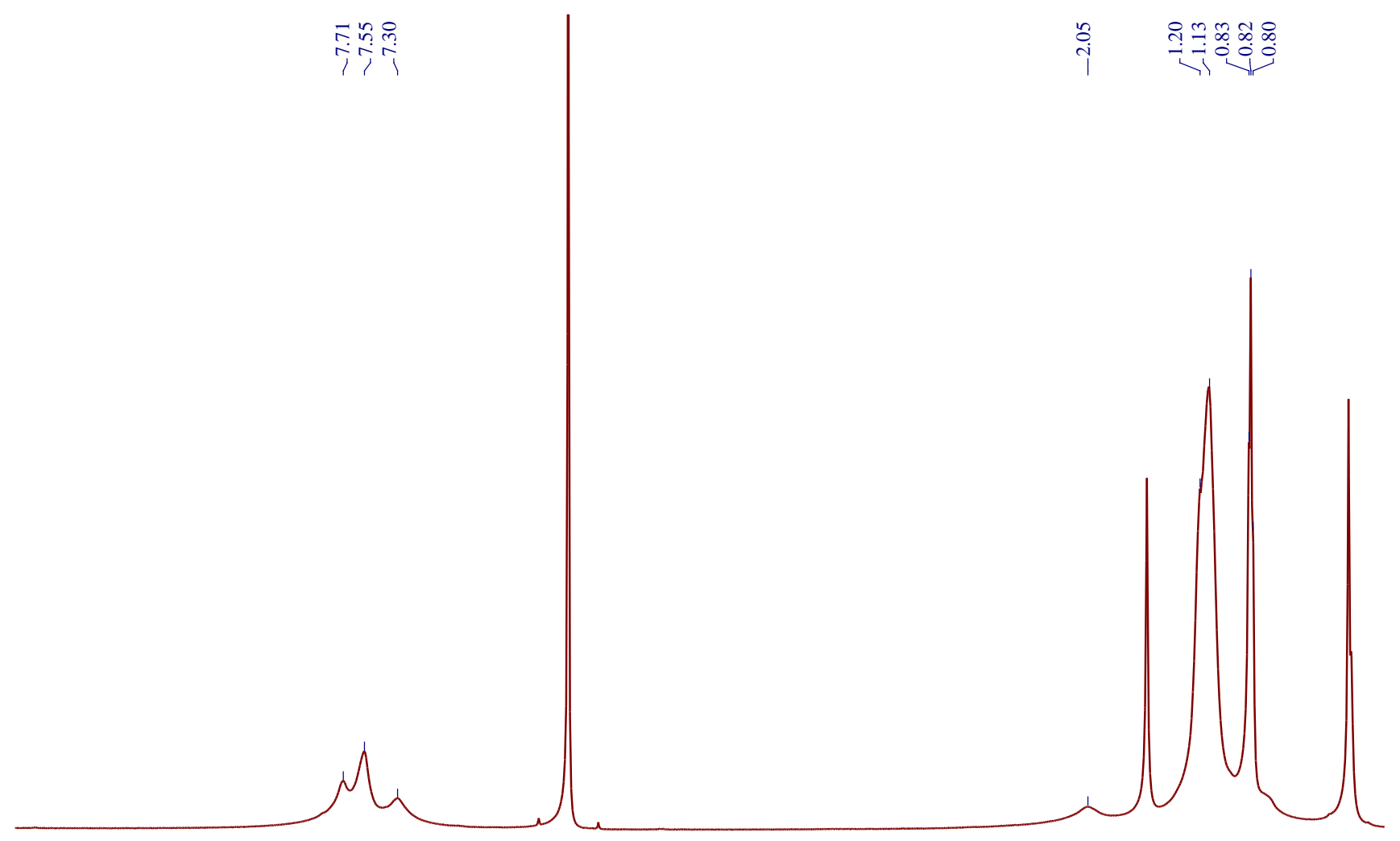

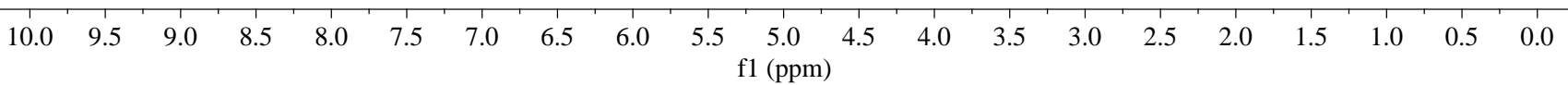


P(DB VE-co-C10)

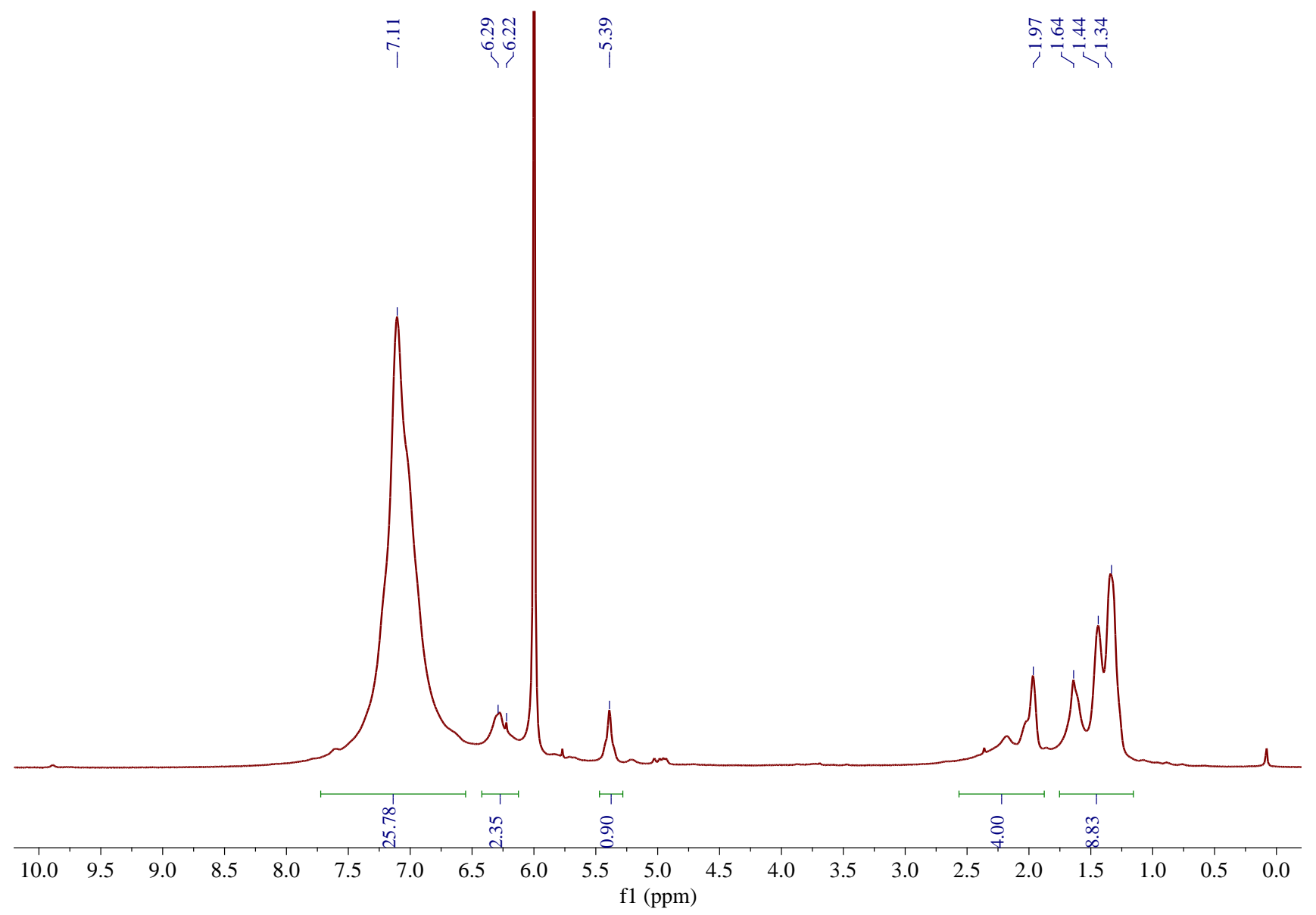


P(DDBV-co-C10)

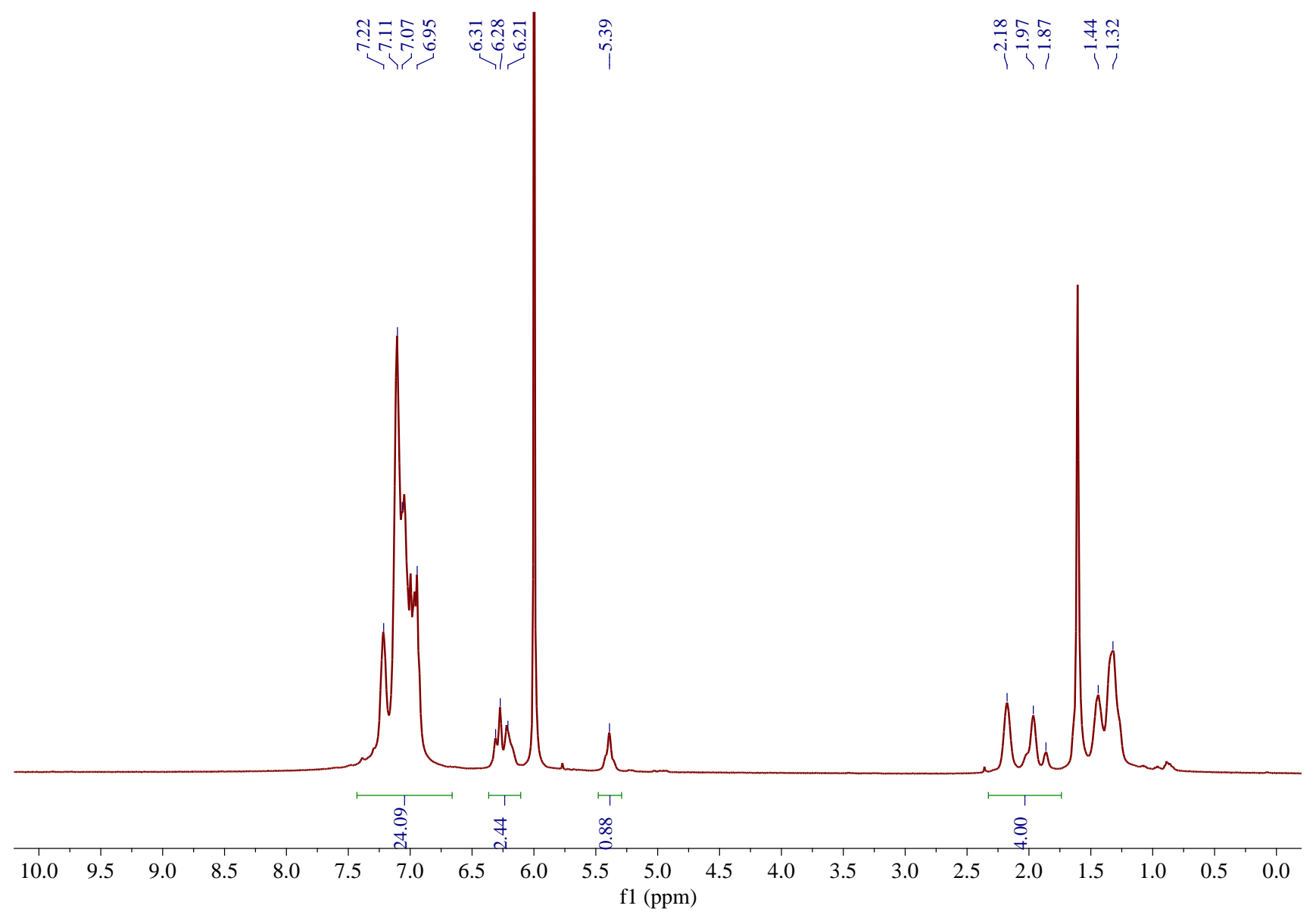




\section{P(DB VE-co-Flu)}

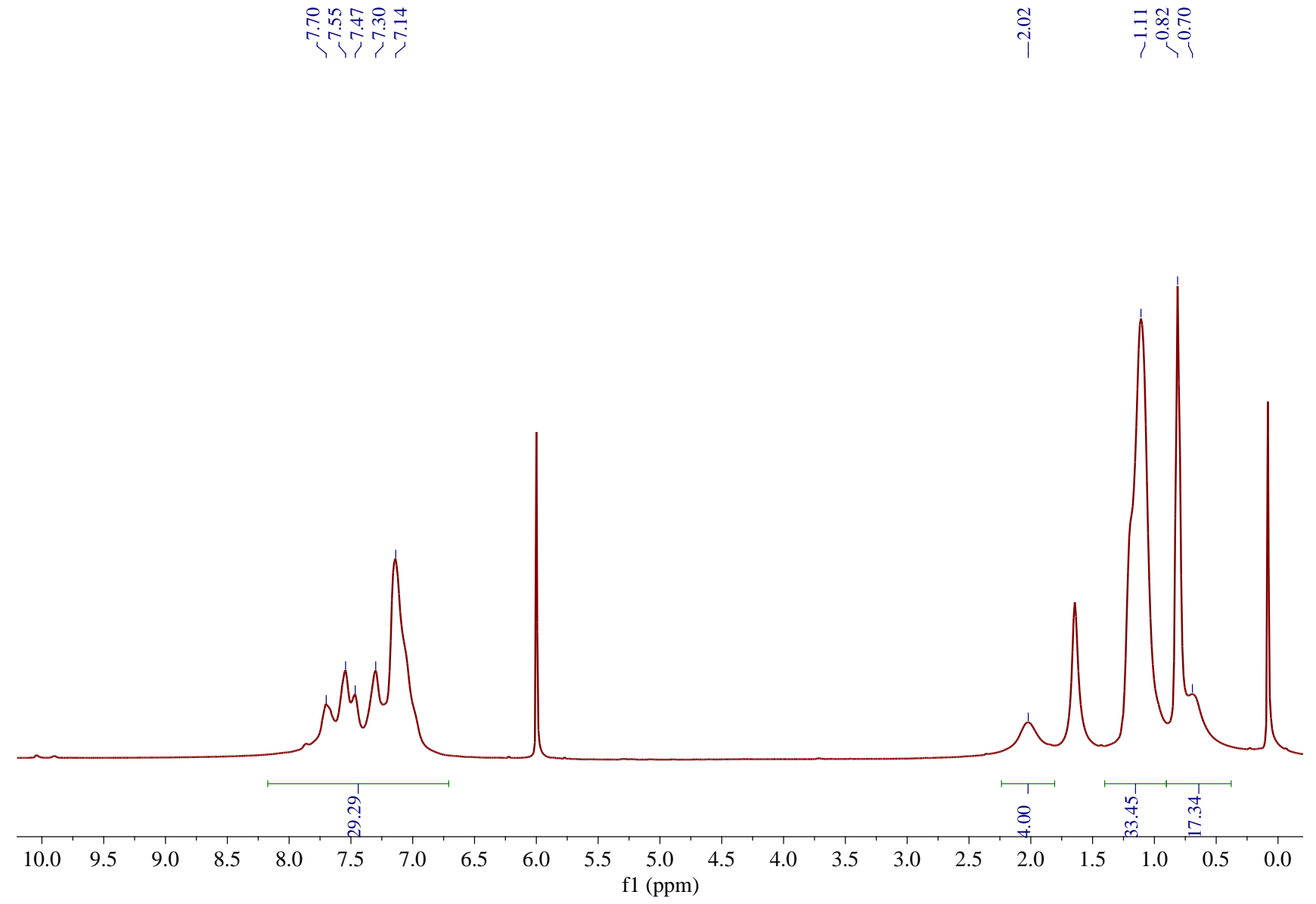


P(DDBV-co-Flu)

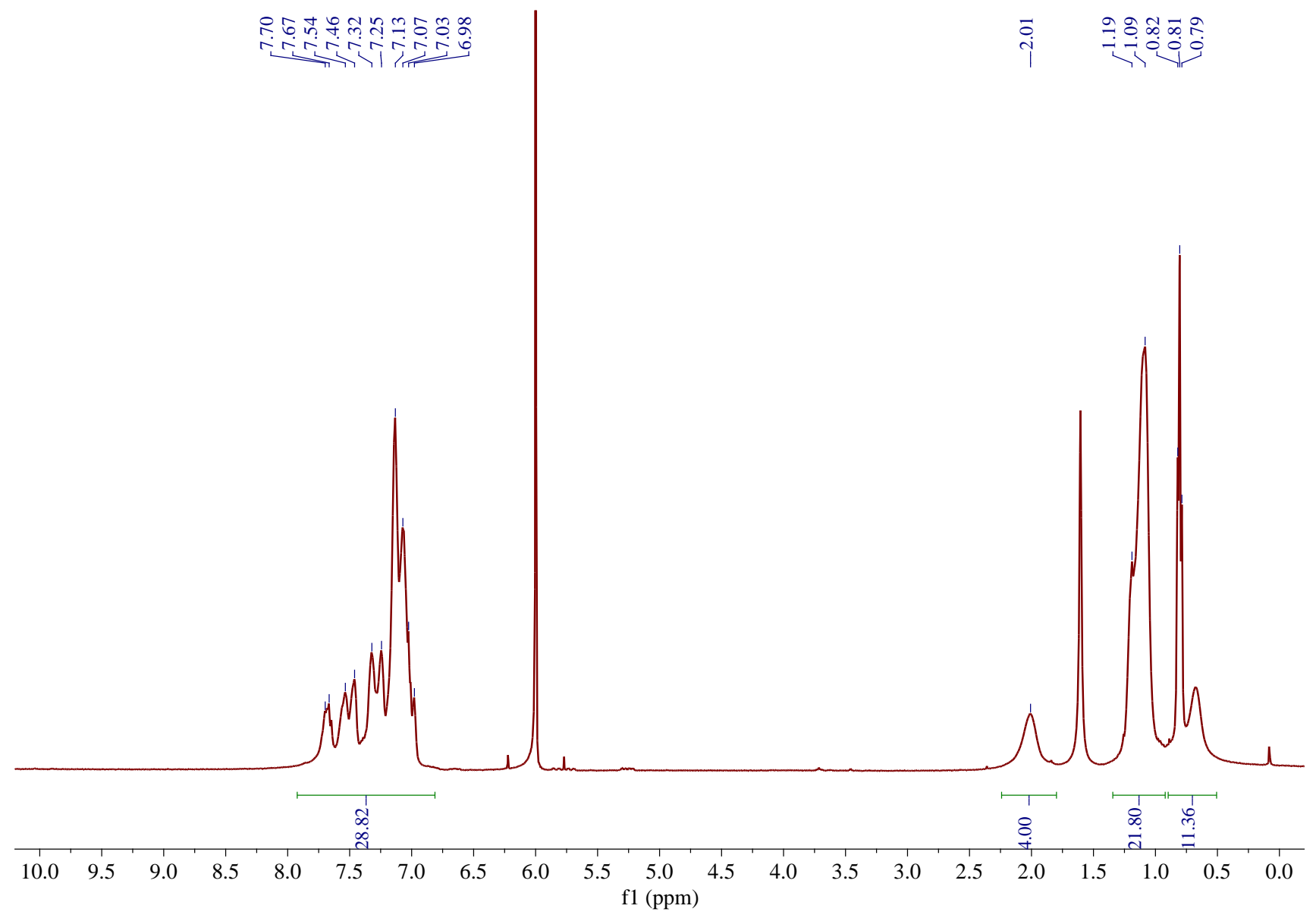


P(DB VE-co-Ben)

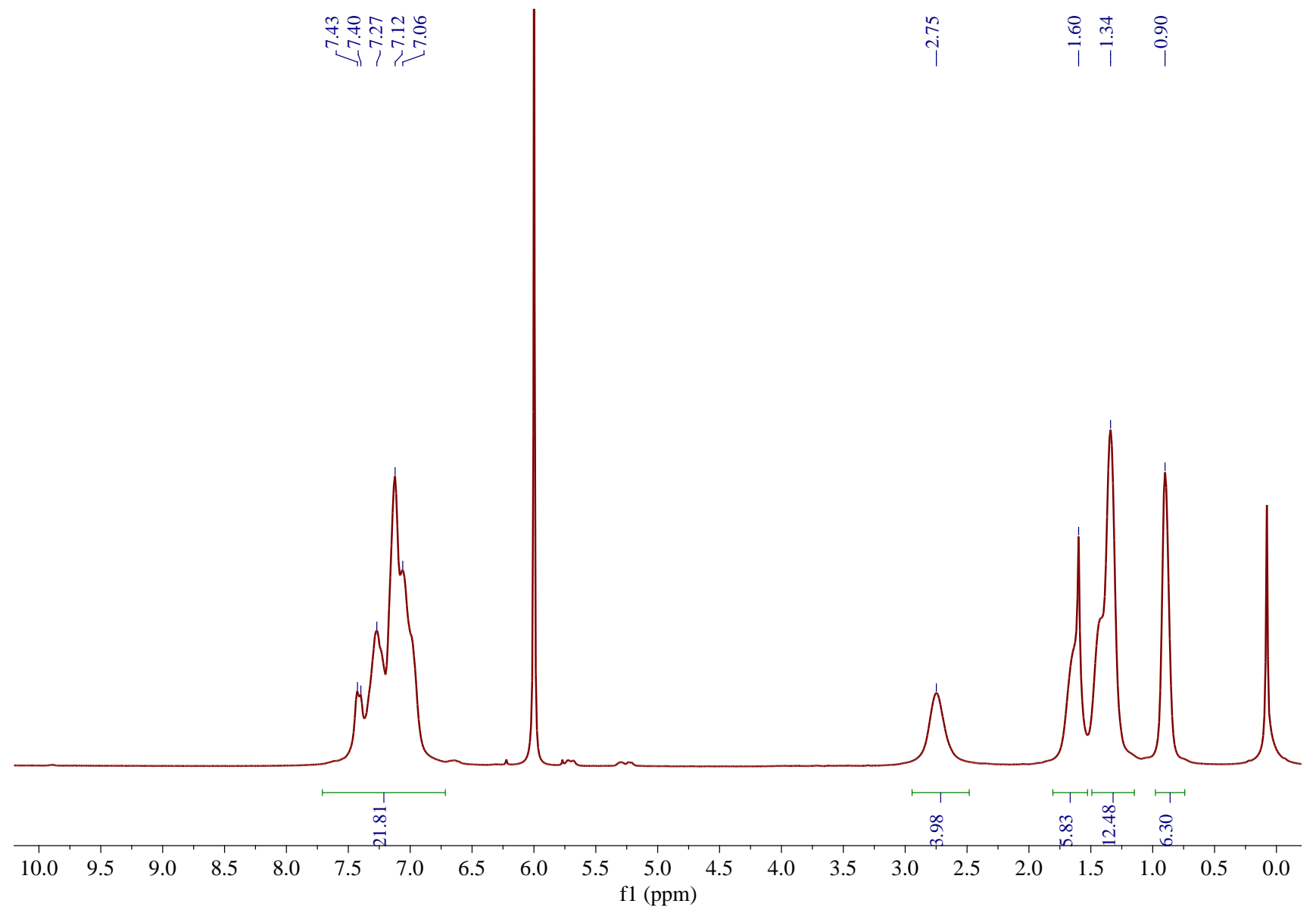


P(DDBV-co-Ben)

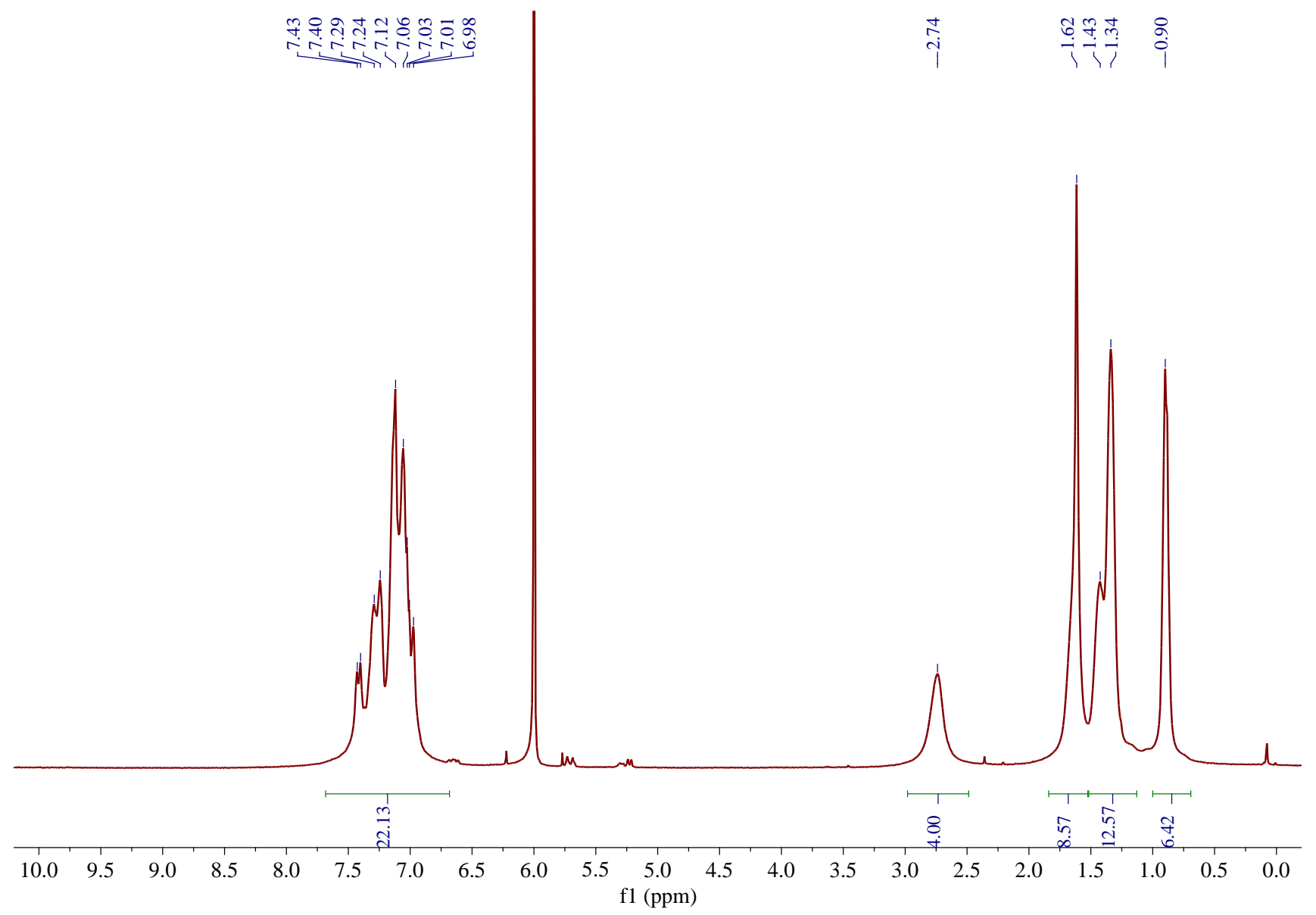

